\title{
Ageing and Caring as Couples with Disabilities
}

\author{
Joy Torgé
}

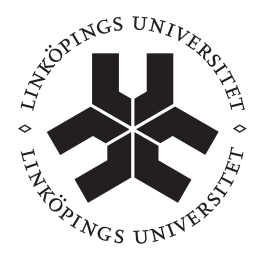

\section{Linköping University}

Linköping Studies in Arts and Science No. 604

Linköping University, Department of Social and Welfare Studies

NISAL (National Institute for the Study of Ageing and Later Life)

Norrköping 2014 
Linköping Studies in Arts and Science $•$ No. 604

At the Faculty of Arts and Sciences at Linköping University, research and doctoral studies are carried out within broad problem areas.

Research is organized in interdisciplinary research environments and doctoral studies mainly in graduate schools. Jointly, they publish the series Linköping Studies in arts and Science. This thesis comes from the National Institute for the Study of Ageing and Later Life at the Department of Social and Welfare Studies.

Distributed by:

Department of Social and Welfare Studies

National Institute for the Study of Ageing and Later Life (NISAL)

Linköping University

60174 Norrköping

Joy Torgé

Ageing and Caring as Couples with Disabilities

Edition 1:1

ISBN 978-91-7519-410-3

ISSN 0282-9800

C Joy Torgé

Department of Social and Welfare Studies 2014

Cover design: Elias B. Guerrero Jr.

Cover illustration: Jamie Bauza

Printed by LiU-Tryck, Linköping 2014 


\section{Abstract}

In gerontology and care research, care is often studied in ways in which older people and people with disabilities are portrayed as dependent on the care of younger or non-disabled people. This thesis, in contrast, studies care provided by people that are both old and have physical disabilities.

The thesis explores how care is actualized and experienced by older couples who both have long-term or lifelong disabilities and investigates the implications of this caring in the couples' lives. Nine couples between 60 and 84 years old, of whom most had had disabilities for over 20 years, were interviewed as dyads; a process also conjoint interviewing. These interviews were analysed using grounded theory methods of coding and constant comparison. The results of the thesis confirm that it can make sense to be a carer even if one also needs care in everyday life. Meanwhile, the analysis also considers how conjoint interviewing resulted in relational and performative data about mutual care. The study helps explain the significance helping a partner despite having other sources of formal support and the difficulties of providing this help oneself. Finally, in a study whose participants are growing old together with disabilities, the results also show that the couples could regard themselves as ageing advantageously compared to other groups.

Through its focus on caring for and by older people with disabilities, this thesis is at the intersection of social gerontology, care research and disability studies. However, from its interdisciplinary perspective, it can also challenge established discourses in these fields. Specifically, the study problematizes the absence of a care discourse in disability studies and the mostly age- and functioncoded ways in which care is discussed in care research. The thesis problematizes dichotomies used in understanding care, such as roles of carers/care receiver, caring/servicing and dependence/independence. It also challenges established ways of thinking about successful ageing. Lastly, the thesis contributes to the still growing literature on ageing with a disability.

Keywords: informal care, mutual care, spousal care, physical disability, ageing with disability, lifecourse, later life, couples, qualitative study, dyadic interviews, conjoint interviews, grounded theory 



\section{Acknowledgements}

Many people helped me to pull this work through. This thesis has had hours of input from my supervisors Eva Jeppsson Grassman, Anna Whitaker and Lotta Holme. It's a privilege to have such an experienced main supervisor as Eva who gave gentle prodding while allowing me to work independently. Anna's attention to detail saved me from inconsistencies, and Lotta always offered concerned and very sensible advice. Their support has been invaluable.

My colleagues at NISAL contributed to my work in other ways. Among the senior researchers, I would like to especially thank Annika Taghizadeh Larsson, Elisabet Cedersund and Lars Andersson. Annika's unfailing good humour is admirable, and it was very stimulating to work with her on Paper IV. Elisabet made it possible for me to hire a professional editing service for the introductory text, and Lars's open door meant that I often walked across the corridor if I needed answers to quick questions.

Among the PhD group at NISAL, I would like to extend my thanks especially to Ida Kåhlin and Magnus Broström. Despite her own hectic schedule, Ida offered to read and comment on parts of my manuscript. She also reminded me of the importance of using consistent and non-disablist language. Magnus and I share an office wall between us, and with that also countless of reflections and frustrations about scientific writing.

Work isn't everything, but I feel fortunate to have many wonderful and heart-warming friends who also supported me in my work. Without their understanding, offers of distraction and concern, who knows where'd I'd be? Anna Martin, besides being a reliable friend, provided me with fantastic service as administrator at NISAL and made sure I had all the administrative assistance I needed with this thesis. My marathon buddy Susanne Urban personally knows how thesis writing is a kind of emotionally- and physically- draining endurance sport. We enjoyed a few beers along the way. I also shared the good times and the bad times with friends who are PhD colleagues at other departments: Kirsten Stoewer, Susan Riedel and Kristian Gjessing. Kirsten is practically one of my oldest friends since my move to Sweden, and a trusted friend in need. Both Susan and Kristian have been enjoyable companions in the outdoors, på tur, when I needed a break from writing. Susan's cheer and optimism is contagious! 
Meanwhile, Kristian's mix of openness, good humour and honest advice saved me many times from an ailment that afflicts many academicians: overthinking. I want to thank him for always being prepared to help. Among lots of other things, he proofread Paper II and checked the final documents before press time.

Aesthetic form makes for more pleasant reading. For giving this thesis its final look, I'm indebted to Karin André, Elias Guerrero Jr. and Jamie Bauza. My good friend Karin generously provided me with her own style sheet, which I tweaked for the final layout of this thesis. Karin also helped me stay sane with stories of her own $\mathrm{PhD}$ experiences, and she is an inspiring reminder that $\mathrm{PhD}$ students actually do make it "to the other side"! My brother Elias, together with illustrator Jamie Bauza, fixed together the fantastic cover for this book. I was wowed when I saw the final version. I also admire Elias for giving me the best words of advice I've heard in many years, during crunch time. His perspectives from publishing have been invaluable: just as in playing darts, the target is bigger than the bull's eye!

With the sheer amount of time spent completing a thesis, it becomes somewhat of a family matter where everyone's cheering for you to get to the finish line. Göran Andersson, Margareta Ekdahl and Mats Persson are the closest people that resemble my family in Sweden. Göran provided genuine support and encouragement through these years. To Margareta and Mats, I'm especially grateful for the week I spent in their house, med helpension, writing the bulk of the introductory text. Their home has been my workshop and my refuge. Lots of problems were solved during my walks with Margareta, and Mats very thoroughly edited my Swedish summary, down to the last comma.

My own family, the Guerreros, have been wonderful. Thanks go to my siblings Elias, Marita and Lea for always being around, for their concern and for always making me laugh. I also dedicate this thesis to my parents Amelia and Elias Guerrero, because without their moral, intellectual, emotional and financial support, none of this would really have been possible. I mention this because Swedes usually take their free education for granted. Since the Philippines does not have a system of student loans, I have an incalculable debt of gratitude to mom and dad for taking on the work and debts themselves, for the sake of their children's education. Despite their work, they never bugged me about my grades; nor did they react when I wanted to take a degree in something as impractical as Philosophy. I want to thank them for their trust in me, and for supporting me all of the way in so many aspects of my life. Maraming salamat!

Finally, on many times during the writing of this thesis, I really wished that I had the good company of Marcus Torgé. Seeing this work come to a close without him was just as hard as the writing itself. I'll always be grateful to him in many ways.

Norrköping, 2 February 2014

Joy Torgé 


\section{Contents}

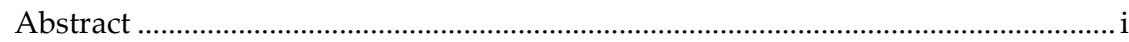

Acknowledgements .............................................................................................ii

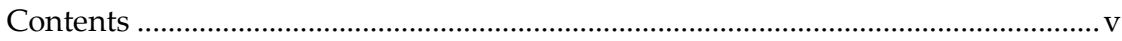

List of papers ………..........................................................................................

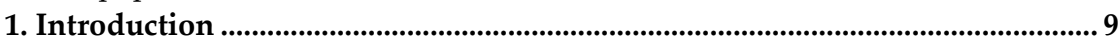

Relevance of the study - Literature review ……............................................... 10

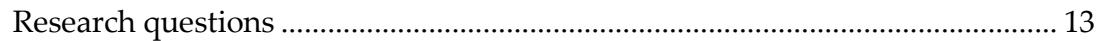

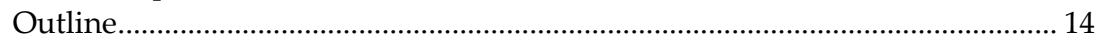

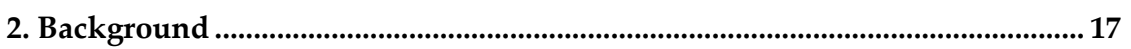

Swedish social policy and research context ......................................................... 17

The tension between care- and disability research .............................................. 20

The perspectives of this thesis .............................................................................. 23

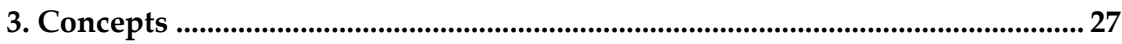

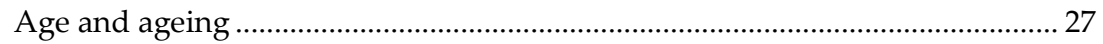

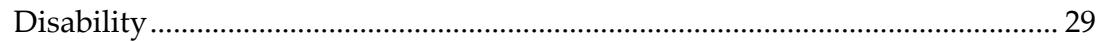

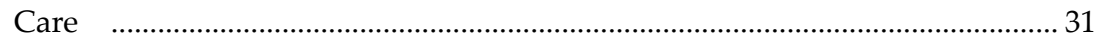

4. Methodology and methodological considerations ................................................. 33

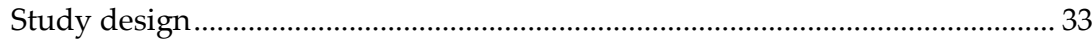

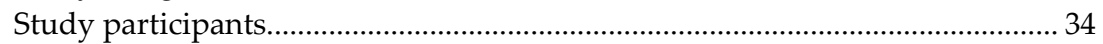

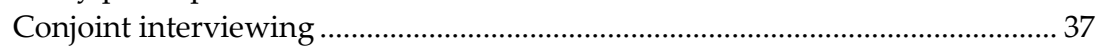

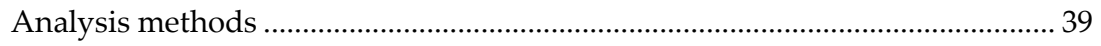

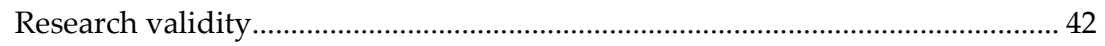

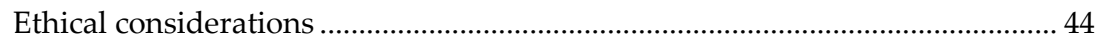

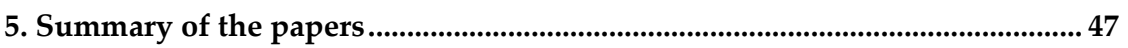

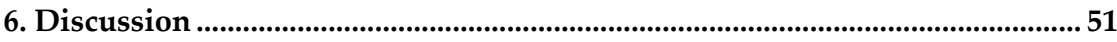

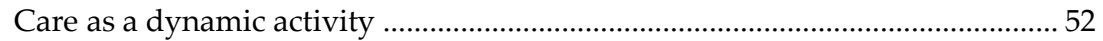

The diversity of ageing experiences................................................................... 55

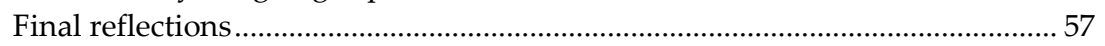

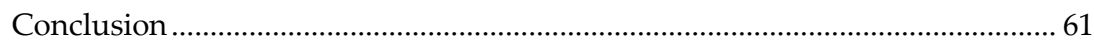

Summary in Swedish Åldrande och omsorg hos par med funktionshinder .................63

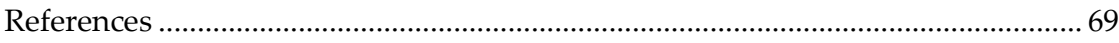

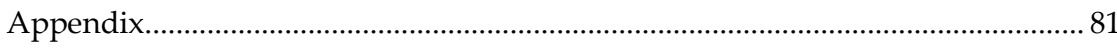





\section{List of papers}

The thesis is based on the following papers, which are referred to in the text by the corresponding Roman numerals.

I Torgé, Cristina Joy (2013). Ageing and care among disabled couples. In E. Jeppsson Grassman \& A. Whitaker. (Eds.), Ageing with disability. A lifecourse perspective (pp. 109-127). Bristol: Policy Press.

II Torgé, Cristina Joy (2013). Using conjoint interviews with couples that have been living with disabilities and illnesses for a long timeImplications and insights. Qualitative Studies, 4(2), 100-113.

III Torgé, Cristina Joy (2014). Freedom and imperative: Mutual care between older spouses with physical disabilities. Journal of Family Nursing. Published online ahead of print 6 February 2014. DOI: $10.1177 / 1074840714524058$

IV Torgé, Cristina Joy and Taghizadeh Larsson, Annika (submitted manuscript). Older couples with long-term disabilities: Multiple jeopardy or successful ageing?

Papers I, II and III are re-printed with permission from the publishers Policy Press, Qualitative Studies / The State and University Library of Aarhus, and Sage. 



\section{Introduction}

This thesis offers an alternative exploration of informal care, beyond traditional discussions in elder care, based on interviews with a group of older couples where both partners had lived with long-term or lifelong physical disabilities. This group-older people with disabilities-would not traditionally be called carers. On the contrary, their high age, long life of disability and family situation would tend to suggest that they live in a situation of multiple disadvantages and should instead be subjects of care. But many older people who have disabilities can also be agents in another way, as givers of care to other family members. What if we explore the caregiving by and between people that are often portrayed as the receivers of care? One does not, for example, often hear of an 83year-old carer with post-polio or a 65-year old carer using a wheelchair, who cares for his/her spouse who is also a wheelchair user. But what if these people said that they chose to help their partner with basic care work despite ageing with disabilities themselves and despite the availability of formal support? These and other examples appear in the interviews that form the basis of this thesis, which I conducted with older Swedish couples with long-term or lifelong disabilities. These are not traditional images of caring; nevertheless, they are characterized by agency and judgment in real-life responsibilities of care (see Sevenhuijsen, 1998). They also give a different picture of care: one that calls into question our traditional understandings of what care is and who carers are.

The aims of this thesis are to explore how care is actualized and experienced by couples that are ageing together with long-term or lifelong disabilities, and to investigate the implications of this caring in the couples' lives. On the one hand, there is a theoretical ambition to understand care outside the dichotomies classically used to frame it, such as non-disabled/with a disability, old/young, dependence/independence and caring/servicing, by exploring care between ageing partners with disabilities. On the other hand, there is also an ambition to contribute empirically, by giving voice to a group of older people whose experiences of ageing have seldom informed gerontological literature.

The study at hand is at the boundary of three research areas. As a work in social gerontology, it deals with older couples' experiences of ageing with longterm or lifelong disabilities. I explore how the couples' experiences of growing 
old together inevitably involve care concerns that are in turn shaped by the long life lived with disabilities. Furthermore, through discussing informal care in the context of people with disabilities, this research also touches on care research and disability studies. From the perspective of care research, the thesis deals with informal caring for and by older people. I consider older people as care resources and study how older people who have disabilities experience caring for a spouse. From a disability studies perspective, I problematize the "care invisibility" of people with disabilities and explore the significance of informal caring for and by people with disabilities.

\section{Relevance of the study - Literature review}

Social gerontology, care research and disability studies all deal with people in need of help and support, but have different points of departure. Although age, disability and informal care are often discussed together in the context of older people with (presumably) late-onset disability, informal caring is seldom explored in the lives of older adults with long-term disabilities, in any of these three research areas. The reasons for this gap are partly demographic, but could also be explained by how the research areas themselves have developed different focuses regarding care.

\section{Ageing with disability}

Research on ageing with long-term or lifelong disability is itself relatively new, both from an international perspective (e.g. Putnam 2012) as well as in a Nordic context (Thorsen \& Jeppsson Grassman, 2012; Jeppsson Grassman \& Whitaker, 2013). This is often attributed to the demographic trend that it has only been in past decades that groups of people with extensive or lasting disabilities have been able to live long lives and reach what is thought of as "old age" (Agree, 2014). Due to advancements in welfare and medicine, many people with earlyonset disabilities can now live longer than in the past (Naidoo, Putnam \& Spindel, 2012; LaPlante, 2014). This group, as well as younger generations of people with disabilities, now have the possibility to "experience the benefits and challenges of ageing in adulthood", which may include higher education, family building, career, and an active old age (LaPlante, 2014). However, they may also face special difficulties regarding, for instance, accelerated effects of ageing or accessing care (LaPlante, 2014; Gilson \& Netting, 1997). Persons ageing with disabilities also seem to belong to an unclear category, and as such may experience double stigmatization (Thorsen, 2003).

The new phenomenon of reaching old age with early-onset disabilities has called for new knowledge about how such ageing is experienced. Others point out how it has only been in the past 30 years that there has been an awareness of issues regarding ageing with disabilities, and that ageing research and disability 
research remain disparate (Putnam, 2012; Moll \& Cott, 2013). For instance, although there is much research on people with disabilities as early adults, there is less knowledge on people with long-term disabilities in later life (Yorkston, McMullan, Molton \& Jensen, 2010). The disability processes related to ageing are also well-researched, but not the pathways of the people growing old with these disabilities (Agree, 2014). Thus, recent works that try to fill this gap refer to the important distinction between research on "ageing with disability", which is still underexplored, and research on "ageing into disability" that has characterized the majority of previous works on impairments and high age (Yorkston et al., 2010; Washko, Campbell \& Tilly, 2012; LaPlante, 2014; Monahan \& Wolf, 2014). A literature search I conducted in Scopus on "ageing with disability" showed that while earlier texts primarily dealt with the medical dimensions of disability such as rehabilitation, recent publications, especially in the past three years, have begun to look at "ageing with disability" as a modern phenomenon in itself with biographical, social, and policy dimensions. One other observation about the literature review is that the calls to synthesize ageing- and disability perspectives have often come from gerontological social work (e.g. Bigby, 2004; Putnam, 2007, 2012; Washko et al., 2012). This is because people ageing with disabilities are identified as a new challenge to care service provision. The new clientele may find themselves in-between ageing- and disability-based services, creating the need for knowledge about the group to better organize formal services (Putnam, 2007; Spindel, Campbell \& Mendez, 2012). However, despite the growing research interest from policy and practice about persons ageing with disability, others point out that there has been little impact in traditional research in gerontology (Spindel et al., 2012).

\section{Different focuses on care}

The absence of research on informal caring among adults ageing with long-term disability could also be traced to the different disciplinary focuses of gerontology, care research and disability studies when it comes to care. There is broad international research on gerontology, policy research and care research on the practice of social care for older people and its distribution among different societal actors, which include the family. For instance, at a macro-level, these studies investigate the distribution of elder care between the informal sector and other care providers (e.g. Bettio \& Plantenga, 2004; Lyon \& Glucksmann, 2008; Pavolini \& Ranchi, 2008; Johansson, Long \& Parker, 2011). At a micro-level, the provision of care for an older family member has been studied in terms of its different implications for the carers. Different degrees of social reliance on informal care are said to affect women's possibilities of combining paid labour with care responsibilities (e.g. Pavolini \& Ranchi, 2008). Caring for an older parent or spouse is also often linked with psychological burdens for the carer (Lavela \& Ather, 2010; Davis, Gilliss, Deshefy-Longhi, Chestnutt \& Molloy, 2011). 
By taking the care of older people as a given, however, there is also a tendency in these studies to frame the growing ageing population as a growing challenge for provision of welfare and informal care. Emotive words such as "the growing burden" of older people reflect how older people are often framed as dependents in the social care relationship (Shakespeare, 2000b).

Meanwhile, studies on support for people with disabilities have not had the same focus on the practice and providers of informal care. At a macro-level, research on support for people with disabilities has rejected familialistic and institutional care, in favour of a view of help as a social right (Shakespeare, 2000a, 2006; see Chapter 2). Overviews of the major journals on disability reveal that the informal caring discourse that is common in gerontology remains scarce in a disability context (Jeppsson Grassman, Whitaker \& Taghizadeh Larsson, 2009; Taghizadeh Larsson, 2012). This is also reflected in research on the micro-level, where there are few studies about carers for people with disabilities that are not personal assistants (Szebehely \& Trydegård, 2007). Others comment that family care seems to have an ambivalent place in disability studies, where it is seen as something that could potentially threaten the political struggle for an autonomous adult life independent of help from the family (Jeppsson Grassman et al., 2009; Whitaker, 2013).

That said, there is no reason to believe that informal caring by the family would be less important for people with disabilities compared to older people in general. As Jeppsson Grassman et al. (2009) has been able to show from a Swedish context, informal caring to people with long-term disabilities is actually quite common. Internationally, many people with disabilities also regard themselves as primary carers to others (Australian Bureau of Statistics, 2009; Office for National Statistics, 2009). With the growing number of people ageing with disabilities, families where more than one person has a disability are also becoming more common, which also has implications for family caring (Miller \& Morgan, 1980; Brown, 1996; LaPlante, Carlson, Kaye \& Bradsher, 1996; Swedish Research Institute for Disability Policy, 2005; Wang, 2005). Yet, surprisingly little is known about the experiences and implications of informal caring in the lives of people with disabilities, as either receivers or providers of such care. Even less is known about how these experiences interact with high age, as people with disabilities grow older, receive informal help, and also give informal help to others.

So, more specifically, it is ageing with a disability, and informal caring of people with disabilities that are not widely explored in social gerontology, care research or disability studies, in either Swedish or international research. The consequence of these diverging research traditions, others observe, is that an empowermentfocused discourse that otherwise characterizes disability studies is still largely missing in gerontology, where older people instead tend to be seen as a care burden (Oldman, 2002). Conversely, disability studies that have focused on 
younger adults with disabilities not only lack perspectives that take the long life with disability - and high age with disability - into account (Jönson \& Taghizadeh Larsson, 2009), but also disregard the significance of informal care for people with disabilities. Priestly (2003) and Oldman (2002) link the diverging research traditions with the mutual distancing between people with disabilities and older people. Disability groups seem to distance themselves from issues relating to old age and dependence, by focusing on social rights and issues in mid-life. Conversely, the emphasis on personal responsibility for active ageing also serves to discursively distance older people from negative images of disability. A look into of these disparate research traditions and missing perspectives, however, is becoming more relevant as people with long-term and lifelong disabilities are now reaching old age. This group may find themselves "in between discourses" of being framed as either older receivers of social care or older adults with support needs. They could also be older carers while simultaneously being older family members in need of care.

The knowledge gaps that appear at the intersection of these research areas is an exciting, fruitful, but also a challenging starting point for my study. The experience of growing old together with disabilities, and the care concerns that a long life together with disabilities entail, have not yet been widely explored and are the subject of this thesis. In this study, I explore informal caregiving between people that are ageing with disabilities. This was done through interviews with older couples, in which both partners had lived with disabilities from birth, youth or middle-age. Influences from social gerontology, care research and disability studies are found in the study as I look the couples' experiences of ageing together, and explore the care exchanged between them.

\section{Research questions}

In accordance with the aim of the study, the overarching questions for this thesis are: How is care actualized and experienced by couples that are ageing together with long-term or lifelong disabilities? What are the implications of this caring in the couples' lives, as they grow older with disabilities? These questions were explored through qualitative, conjoint interviews with nine older couples with disabilities, and through an analysis that used grounded theory methods. The four papers included in this thesis are the results of my analysis, and shed light on the research questions through different lenses. I also maintain that the chronological order of the papers reflects the development of my own analytical process, which has led to specific research questions:

- In Paper I, I asked if and how care could be understood in the context of my interview participants. The questions raised there are: Does it make sense to simultaneously be dependent on help and care in everyday life and consider oneself a caregiver? How are help and care manifested in a relationship 
where both have disabilities? How do ageing and disability trajectories affect the preconditions for spousal caring?

- In Paper II, while still in the middle of my analysis, I had to reflect on the consequences of the interview method for the kinds of answers I was getting about spousal care and the possibilities for interpretation. Paper II is thus a methods article that asks: What are the characteristics of the data generated in these conjoint interviews? How can the resulting data contribute to understanding care in disability contexts? What are the potentials and limitations of the method?

- As my analysis progressed, it also became clear that the participants' experiences of mutual caring occurred in a context where they also received different kinds of formal help. These questions for Paper III emerged: Why do couples experiencing physical disabilities provide different kinds of help for each other, including what may be considered as heavy care tasks, despite the existence of formal care and welfare systems aimed at them and those they care for? How does the relationship between them shape the experience of mutual caregiving?

- Paper IV appeared from unexpected themes that I observed during the course of the analysis. Namely, while the couples reported worsening disabilities, they also described themselves as being advantaged and as maintaining a high level of activity in some areas of life. Framed as a critical discussion of established notions of successful ageing that take high physical function as a prerequisite, Paper IV deals with the following questions: How and in what respects did the couples consider themselves as advantaged, despite ageing together with disabilities? How did the couples manage to maintain a high level of activity in some areas of life, despite worsening disability in old age?

As a whole, the study can contribute to the interdisciplinary research about ageing, disability and informal care. Furthermore, this study has implications for social work and family nursing practice. For instance, it can contribute to a family perspective in understanding the motivations for, and implications of, continuing to give informal care despite disability.

\section{Outline}

In this chapter (Chapter 1), I have given a general picture of the thesis, its aims and research questions. The subsequent chapters will cover the following:

- Background: the important social- and research contexts that surround the research area at hand (Chapter 2);

- Concepts: showing how age, disability and care intersect and interact, and 
how these concepts have been used in different ways in the papers (Chapter 3);

- Methodology and methodological considerations: where I describe my methods for data generation and analysis, as well as the methodological and ethical implications of the methods chosen (Chapter 4);

- Summary of the papers: showing the main findings of the texts included in this thesis (Chapter 5);

- And Discussion: where I underline some of the important insights generated in the four papers as a whole, and the contributions of the thesis to research (Chapter 6).

This introductory text is then followed by a Summary in Swedish, and Papers I, II, III and IV. 



\section{Background}

The intention of this chapter is to give the background to the papers. First, I present the important social- and research contexts relevant to the research area. I introduce the research program under which this study was made, which belongs in a Swedish social- and research context. I also discuss the tension between care research and disability studies in international literature that seemed to have resulted in the "care invisibility" of people with disabilities. Secondly, I outline the perspectives of this thesis by discussing how I see the concept of care in this study as a boundary concept. I also discuss the lifecourse perspective that has influenced this research and how the different meanings of temporality sensitized my analysis.

\section{Swedish social policy and research context}

This thesis was written as part of a research program in Linköping University called Forms of Care in Later Life: Agency, Place, Time and Life Course. This multidisciplinary program aimed to develop new research questions and to contribute new theoretical perspectives to the field of ageing and care (Jeppsson Grassman \& Whitaker, 2012). Part of the research program's profile was to explore other ways of studying care for older people, outside the traditional focuses in Nordic research centred on the welfare state and the organization of social care among different sectors (see e.g. Eliasson, 1996; Szebehely, 2005). Rather, an important pillar of this research program was that care should be understood within the specific contexts in which it takes place. A short discussion of the context of Swedish social policy and research is provided in this section, as it helps to understand the context of this thesis and its ambitions.

Sweden, together with other Nordic countries, is often associated with a social democratic welfare regime characterized by ideals of universalism, comprehensive risk coverage, generous benefit levels and egalitarianism (Edebalk, 2000; Jeppsson Grassman, 2010). However, social care is another key element around which one can analyse welfare states (Daly \& Lewis, 2000; Bettio \& Plantenga, 2004; Jeppsson Grassman, 2010). In this respect, the Nordic countries constitute what Daly and Lewis (2000) see as a unique cluster, where provision of elder and child care have been "collectivized". It is argued that in 
the Nordic states, care is acknowledged to be part of social citizenship (Anttonen, 2002). Locally organized care services are funded by taxes and are widely available for all social classes (Daly \& Lewis, 2000). These similarities make it possible to speak of "social service states" or a "Scandinavian social care regime" (Rostgaard \& Szebehely, 2012; Anttonen, 2002). This classification, however, is also contested in literature (Rauch, 2007) and it might be more fruitful to see universalism as an ideal type (Anttonen, 2002).

With the shifting of care from the household to public social services, the Nordic welfare states are also said to be characterized by "de-familialization" (Leitner, 2003). Familialistic policies oblige (and also allow) the family to provide care for members in need, thereby also forcing care receivers to be dependent on their families. De-familialization, on the other hand, "means not only taking away care responsibilities from the family. [It] also reduces the extent to which the satisfaction of individual care needs is dependent on the individual's relation to the family" (Leitner, 2003, p. 358). Naturally, de-familialization does not mean that reliance on family care disappears. Even in the Scandinavian welfare regime, the family is an important agent of care provision (Leitner, 2003). In Sweden, studies maintain that much elder care is provided by families, mostly children and spouses (Szebehely \& Trydegård, 2007). Others point out that the amount of informal care provided has dramatically increased from the 1990s to the 2000s and that one way to explain this might be in terms of civic involvement (Jegermalm \& Jeppsson Grassman, 2012). However, some of this increase in family caring might also be caused by "reverse substitution" and "forced informalization" resulting from cutbacks in home help and institutional care (Johansson, Sundström \& Hassing, 2003; Szebehely \& Trydegård, 2007; Jegermalm \& Jeppsson Grassman, 2012).

The couples that were interviewed for this study are described as being providers of help for their spouses. This is not surprising in light of Swedish statistics that show that care provided for older people in the same household is almost entirely spousal care (Rostgaard \& Szebehely, 2012). However, many of the participants were also receiving formal care targeted at people with disabilities. In contrast to the developments in Swedish elder care, disability reforms in Sweden have not led to increased informalization but rather to an increase in budget resources (Szebehely \& Trydegård, 2007). The mutual care between the interviewed couples appears interesting when considered against the background of the extensive formal care targeted at people with disabilities in Sweden. This is especially interesting in the cases where spousal help was provided despite eligibility for personal assistance.

In Sweden today, social services for people with disabilities are covered by two different laws. People with disabilities are entitled to social services according to the Social Services Act, but certain groups are also covered by the 1993 Act concerning Support and Service for Persons with Certain Functional 
Impairments, or LSS (Swedish abbreviation; SFS 1993:387). The latter could be seen as supplementary to basic social services, but is better understood as a rights statute for certain categories of people with extensive disabilities (Clevnert \& Johansson, 2007; Barron, Michailakis \& Söder, 2000; Lindqvist, 2012). ${ }^{1}$ This Act gives the entitled groups the legal right to ten different services including counselling, a companion service, a relief service for parents of children with disabilities, housing with special services or an adapted home, daily activities, and personal assistance.

Among these different services, personal assistance gives the most comprehensive type of support to those with the most help needs. It is a type of home care for people that need basic assistance in daily life, for instance in dressing, eating, communication and personal hygiene (Ahlström \& Wadensten, 2011). The Swedish system of personal assistance allows the entitled groups the right to employ a personal assistant, either by themselves or through a provider, thus increasing their influence on how support is provided (Clevnert \& Johansson, 2007). Sweden's personal assistance system is thought to be unique in its extent (Jeppsson Grassman \& Whitaker, 2013) and is considered an outstandingly successful element of the Swedish welfare system (Clevnert \& Johansson, 2007).

It was mentioned that elder care in Sweden seems to be characterized by an increased reliance on informal care (Szebehely \& Trydegård, 2007; Rauch, 2007). Meanwhile, formal support and services for people with disabilities are increasing, especially for those aged 60-64 (Clevnert \& Johansson, 2007). ${ }^{2}$ These contrasting patterns of informalization and formalization are also reflected in the Swedish care research. The prevalence of informal caring for older people in Sweden has been studied since the early 1990s (Szebehely, 2005; Johansson et al., 2011). Preceding this there was already a strong Nordic research tradition on the organization of care for older people and how it is distributed between the public and informal sectors. In contrast, Swedish research on help and support for people with disabilities, like international literature, is characterized by the relative invisibility of informal care and a focus on personal assistance. The family's perspective and experiences of personal assistance given to a relative are often ignored (Ahlström \& Wadensten, 2011). There are also few studies about other groups than personal assistants providing care for people with disabilities

\footnotetext{
1 These disability categories according to LSS are translated by Clevnert and Johansson (2007) as: "[persons] with intellectual impairments or autism, [persons] who have received brain injuries as adults with a consequent impairment of their intellectual capacity, and [persons] who have great and permanent physical or mental functional impairments that cause considerable difficulties in daily life and consequently require considerable support and service" (p. 68).

${ }^{2}$ Relevant to this is that a person has to be younger than 65 years old when applying for personal assistance.
} 
(Szebehely \& Trydegård, 2007). This may hide the fact that people with disabilities also receive significant help and care from the families to which they belong. For instance, ageing parents of adults with disabilities could still take on a caregiving responsibility throughout their lives and sometimes even choose to work as personal assistants for their children (Whitaker, 2013). As with older people, it is also likely that spousal care constitutes a significant part of the help exchanged in the household.

The invisibility of informal care in research on disability is partly attributed to the tension between care research and disability studies, which is discussed in the next section. Although this tension arguably stems from a British debate, it also has influences on how care is conceptualized, discussed or not discussed elsewhere, for instance in Scandinavian research.

\section{The tension between care- and disability research}

As many other researchers have observed, care research and disability studies have discussed the concept of care in different ways, leading to what may seem as disparate or even opposing perspectives (Lloyd, 2001; Becket, 2007; Kröger, 2009). This tension is largely attributed to how care has been defined and discussed in care research, and subsequently, the conceptual baggage linking care with dependency (Lloyd, 2001; Fine \& Glendinning, 2005; Beckett, 2007; Kröger, 2009). This background makes it potentially difficult to talk about informal care for adults with disabilities, such as that attempted in this thesis, so I offer a short discussion of the debate in his section.

\section{Care research}

In Britain, the focus of early care research in the 1980s was the invisible and unpaid work done by women in the domestic sphere (e.g. Graham, 1983; Finch \& Groves, 1983). Care work was described as physically and emotionally taxing work which had economic and social costs for women. At the same time, women were socially expected to carry out this work as a labour of love (Finch \& Groves, 1983). Later, similar issues - but still with a focus on the carer-were discussed in the context of formal care systems. Subsequent research combined elements of social policy, economics and welfare studies in studying, for example, the effects of different care systems in terms women's participation in the labour force (e.g. Bettio \& Plantenga, 2004). Scandinavian care research that developed at around the same time focused on the paid carers within the welfare system (Eliasson, 1996).

Over the years, care research has helped form an understanding about the practices and repercussions of caring, both from a macro- and micro level. An important consideration was how to define, study and acknowledge the activity called care in the domestic and public sphere, within social research and policy. 
In the development of care as a concept, however, the functional status of the care receiver-and the relation of dependence-had become the defining characteristic that set care apart from other forms of reciprocity (Wærness, 1996). Within Scandinavian care research, Kari Wærness contributed to this conceptualization of care through the differentiation between "personal service" for people that could make it on their own, and "caring" for people who could not do certain activities themselves (Eliasson, 1996). Typical definitions of care are activities performed for someone "who cannot manage to do these activities him or herself" (Jegermalm, 2005, p. 13) or "people who are not able to take care of themselves", often distinguished as "young children, frail elderly people, and people who are chronically ill or handicapped" (Knijin \& Kremer, 1997, p. 328). Leira and Saracendo (2002) note that "the distinction between caring for dependent persons who are not able to take care of themselves and caring for those who can manage well on their own remain analytically important" in defining caring as an activity (p. 62). In defining care, therefore, there is an emphasis on (lack of) functionality or ability on the part of the care receiver. Consequently, according to disability activists, there has been a tendency in care research to see people with disabilities in terms of their inadequacies, and to frame them as a social burden (Shakespeare, 2000b).

According to Jegermalm (2005), a number of studies suggest that informal care is most commonly practiced by middle-aged women, mostly aged 45-60. Though caring undoubtedly has a gender- and age aspect, one could ask if the overrepresentation of middle-aged women as carers is also a result of how care research has been driven, and what research problems are traditionally chosen. With a strong focus on child- and elder care, the typical carer is almost always a non-disabled woman of working age, taking care of both younger and older "dependants". Those that receive care, in their turn, often become cast in roles of dependency, either because of their age (as being young or old) or their physical ability. Indeed, the roles of younger people, older people and people with disabilities as carers have often been neglected, discredited, or identified as a problem. Young carers have been identified as "victims" of their situation (see Shakespeare, 2000a) while older carers are seen as a vulnerable group that carry a heavy burden when they should instead be supported (Wenger, 1990; Doran, Drever \& Whitehead, 2003). Likewise, mothers with disabilities are often questioned about their capacity to provide good care because of their impairments (Thomas, 1997; J. Morris, 2001; Prilleltensky, 2004). In this way, traditional ways of defining and studying care have caused people with disabilities to become invisible as carers. 


\section{Disability studies}

Care has not been the subject matter of disability studies in the same way as it has in care research. Rather, as disability activism and disability research grew hand in hand, the concept of care came to symbolize one of the causes of oppression of people with disabilities, particularly how care constructs the physical dependency of people with disabilities as a relation of social dependency (J. Morris, 1997; Shakespeare, 2000a; Ratzka, 2007). As Tom Shakespeare (2000a) suggests, the discrediting of the caring roles of children, older people and people with disabilities seems to be built on conceptual "othering".

The criticism of the link between care and dependency also later influenced disability activism, for instance in Independent Living movements that emphasized citizenship and autonomy over institutionalized forms of help (Ratzka, 2007). A strong and often cited statement by Jenny Morris summarizes the tension between the struggle for empowerment by people with disabilities, and being the subject of care: "One cannot, therefore, have care and empowerment", she writes, "for it is the ideology and the practice of caring which has led to the perception of disabled people as powerless" (J. Morris, 1997, p. 54, italics in original). Subsequently, the concept of direct payments and personal assistants represented the rejection of traditional family care and institutionalized care, in favour of a model where individuals with disabilities can take control of how help is provided (Shakespeare, 2006; Lindqvist, 2012).

Arguably, the targets of early criticisms of disability researchers were the pre-determined formal services for people with disabilities. However, through distancing themselves from the notion of care and its emphasis on depersonalized models of help, disability studies also seemed to contribute to the "care invisibility" of adults with disabilities, this time as receivers of informal care. Independence from the family has been an important argument for the right to formal assistance and support. Thus, one reason for the absence of an informal care discourse in disability studies may be the fear of undermining the important and valuable successes of disability policy (Jeppsson Grassman et al., 2009). On the other hand, the significance of informal caring for adults with disabilities may also be hidden behind a rhetoric of self-sufficiency despite impairments. For instance, the significant caring work of the parents of adults with disabilities is often criticized as a hindrance to the adult child's autonomy (Whitaker, 2013). How care has been traditionally defined, and the ambivalent place of care in disability studies, help explain why there is little research on informal caring in the lives of people with disabilities, as either receivers or providers of such care. 


\section{The perspectives of this thesis}

The background discussed above shows that the linking of informal care to a disability context is not self-evident. Meanwhile, discussing informal care in the context of old age seems fairly common, if not taken for granted. This presented challenges, but also possibilities, for discussing care in the lives of the older people with long-term disabilities that were interviewed for this present study. In this thesis, I considered care as a flexible boundary concept. This, together with the lifecourse perspective that takes different meanings of temporality into account, give possibilities for discussing care in other ways than those usually taken up in the disciplinary discourses.

\section{Care as a boundary concept}

In this study, it has been fruitful for me to see care as a boundary concept; that is, a contested but flexible concept that is used differently between disciplines. The notion of boundary concepts was coined by Star and Griesmer to mean "artifacts used by different groups but which, when they cross the boundaries between groups, may be interpreted differently" (in Rhoten, 2004, p. 11). It is also used to illustrate the possibilities and problems of "borrowings" between different disciplines (Klein, 2000). Relevant to this study is that care can not only mean different things depending on actors and situations (Thomas, 1993), but is also a strongly ideological concept (Fine \& Glendinning, 2005). Care research and disability studies have had different points of emphasis when discussing care, and also identify different problems for different stakeholders (Hughes, McKie, Hopkins \& Watson, 2005). The carer with her often unacknowledged care work, and the person with disabilities at risk of being reified in a position of dependence could, it seems, represent opposing sides in the struggle to acknowledge or reject care. This helps explain why, when beginning to read research on care and people with disabilities, there seems to be "little sense that [care research and disability studies] are exploring and explaining different aspects of the same phenomenon" (Fine \& Glendinning, 2005, p. 601).

A number of scholars suggest a possibility for dialogue between these two research areas through revisiting the care concept and broadening discussions of care (Watson, McKie, Hughes, Hopkins \& Gregory, 2004; Hughes et al., 2005). Considering care as a boundary concept, as I have tried to do in this thesis, may be useful in this respect. Julie Thompson Klein, who writes about interdisciplinarity, emphasizes how boundary concepts are negotiable concepts. They are "robust enough to maintain unity across fields but are plastic enough to be manipulated. Weakly structured in common use, they are strongly structured at individual sites. As negotiable entities, they simultaneously delimit and connect. In cognitive terms, they facilitate hybrid intellectual work" (Klein, 2000, p. 12). The concept of care exhibits both generality and particularity as Klein 
describes. Though strongly structured in the disciplinary sites in which they are discussed, care can also be used in a flexible way between these areas. For this study, openness to how care could be defined and discussed, while acknowledging that it could mean different things in different disciplines, provided a window for discussing informal care in the context of adults with disabilities. Hopefully, this also opens up new perspectives.

The empirical challenge for this study was how to describe and acknowledge the informal care given and received by people with disabilities, in a way that does not undermine the importance of social dimensions of disability or the role of formal support. In this respect, studying a group that was "in between different discourses" was a fruitful starting point for this interdisciplinary research. Because my participants could be framed in various ways-as spousal carers or as care receivers with disabilities, as receivers of formal and informal help, and as older people with impairments or ageing adults with disabilities - this guarded against reifying them in any particular discourse. Exploring the experiences of ageing and caring among this group has not only helped me understand the rhetorical boundaries of the different research areas but also allowed me to cross between them through the stories of my participants.

\section{The lifecourse perspective}

This study also adopts a lifecourse perspective that takes different meanings of temporality - and thus different expressions of care-into account. The lifecourse perspective, writes Linda George (2013), "has become the dominant concept for thinking about and understanding the social significance of age and ageing" (p. 149). It is both a research strategy and a theoretical approach that suggests that the experiences of ageing should be understood in the context of the individual's whole life, and that ageing should be seen as a lifelong process. The intersection between personal biography and agency on the one hand, and historical time and social change on the other hand is, according to this perspective, important in understanding variations in the ageing experience (Giele \& Elder, 1998).

The implication of the lifecourse perspective for my study is that both disability and care had to be considered in light of historical and biographical time. On the one hand, disability policy contributes to different aspects of the individual's life, which includes caring within the family. Access to support groups and formal help in everyday life may have made it possible for the interviewed couples in this study to meet and to pursue a relationship despite their help needs. Forms of support and technical aids that have appeared in recent years could also have helped them in their capacities to provide care. On the other hand, the long life lived with disability and one's bodily changes as one grows old could also affect the practice of and possibilities for informal caring. In this way, the historical and social contexts affect the personal sphere, while 
physical aspects of disability also affect agency to make future choices.

The lifecourse approach is also relevant to my research in other ways. First, there is the question of if and how the long life lived with disabilities presents other challenges and experiences than in so-called "normal ageing" (Putnam, 2002). Verbrugge and Yang (2002) suggest that there may not be much difference between "aging with disability" and "disability with aging", since the processes of ageing and disablement interleave throughout the lifecourse. However, people ageing with long-term disabilities may also experience old age differently to those who acquire disabilities in later life. For instance, long-term disability may make the individual more prone to bodily changes as the disability trajectory unfolds, perhaps even accelerating the aging process for some (Gilson \& Netting, 1997). Furthermore, while increased help needs are often expected at high ages, people with early-onset disabilities enter old age already as long-term consumers of care services (Bigby, 2004; Putnam, 2012). The long life lived with disabilities can also affect attitudes to ageing, in terms of one's view of the ageing body and attitudes to care and dependence (Taghizadeh Larsson, 2009; Holme, 2013).

Second, the lifecourse perspective is relevant for this thesis for studying older peoples' experiences within close relationships. The concept of linked lives is one of the important principles in lifecourse research. It is the "recognition that humans are linked to others in complex ways and that these connections are powerful forces in personal biography" (George, 2013, p. 152). The principle of linked lives sensitizes research to the importance of family roles over time, shared experiences, and parallel psychological development in shaping individual lifecourse outcomes. Relations also influence how people act in other life domains such as social participation (George, 2013). Biographical time and historical time also play a role here. Studies suggest that encounters in the current relationship, normative and non-normative events, and social, cultural and historical contexts shape how close relationships are experienced in later life (Blieszner, 2006). An aspect that I found relevant for my study is that being a couple with long-term or lifelong disabilities cannot be taken for granted as a given. The possibility for this group to engage in intimate relationships may have arisen through the positive social attitudes to people with disabilities and available forms of support around the couple (see Shakespeare, Gillespie-Sells \& Davies, 1996).

Within biographical time, ageing together and caring for each other with disabilities can be understood as a shared experience shaped both by social expectations and by bonds of closeness. Caring activities themselves also have a time-space dimension and may involve reciprocity of different forms of care over long timescales where "most people are, at some time, a 'carer', and at others 'cared for'; and often both at the same time" (Bowlby, 2012, p. 2102). Informal care in close relationships can thus be seen as a continuous activity in a landscape of different circumstances that shape the caring activities, but that also can give 
rise to specific concerns (McKie, Gregory \& Bowlby, 2002).

In summary, using care as a boundary concept and using the lifecourse perspective, this study considers ageing as a lifelong process and considers different dimensions of care as partners grow old together with their disabilities. The study considers how events earlier in the couples' relationships and the concept of linked lives shape experiences and expectations as partners care for each other in later life. Throughout the study, I consider older people and people with disabilities as providers and receivers of informal care over the lifecourse. I also acknowledge that care roles are not static and that reciprocity can take on different expressions as the couples age together with their disabilities. 


\section{Concepts}

Throughout the study, I consider both biological and social dimensions of age and disability, and consider the relational and work dimensions of care. The purpose of this section is to introduce some important concepts that appear throughout the thesis. Rather than merely defining these concepts, I also attempt to explain how these different concepts can be understood in relation to each other. For instance, I discuss how people with disabilities can engage with age norms, how ageing and disability processes intersect, and the different approaches to care. I also describe how different concepts are used in different ways in the papers.

\section{Age and ageing}

Age has both chronological and social dimensions. We increase in age with the passage of time, but chronological age also works as an organizing principle in societal institutions (Närvänen, 2004; Bytheway, 2011). The social dimension of age relates to how chronological age orders life events such as starting school, finding employment and retirement. Närvänen and Näsman (2006), for example, demonstrated how various historical and social processes had contributed to the construction of childhood, adolescence and adulthood as socially distinct phases of life. Although Närvänen and Näsman identify blurring between the lifecourse phases, these still tend to have a normative function. Throughout our lives, we adopt and embody norms, ideals and expectations of how it is to "act one's age" and use these norms as a reference to identify what is "normal", expected or "appropriate" for one's age. These norms are used, for example, when a person with disabilities says that "one is active for one's age" despite disabilities.

Age norms, together with the idea of the institutionalized lifecourse, shape our understanding of a "normal life and the 'problems' that arise when individuals or groups 'fail' to make proper progress through it" (Priestly, 2003, p. 26). A common illustration of this is the stage of adulthood, as characterized by independence and autonomy, and as a life phase involving moving away from one's parents, establishing a home, family-building, making one's own decisions, and having one's own source of income. From a disability perspective, one can look at the institutionalized lifecourse in at least two ways. Firstly, depending on 
one's circumstances, a life marked with disability can appear different from that of others'. As a negative result, the normative lifecourse may serve to stigmatize individuals who for different reasons do not fit age-normative ideals such as having an independent and self-sufficient adult life (Priestly, 2003). On the other hand, the awareness that social structures affect the individual's life chances can help underscore how structural or attitudinal barriers exclude people with disabilities from age-structured roles such as building a family, moving away from home and having children (Nirje, 1969; Hunt, 1998). Secondly, it follows that the normative lifecourse can in itself be an identifiable and empowering pattern in a political and social struggle for a "life like others'". Age norms and institutionalized life phases can thus have social and political significance as a normalizing principle for people with disabilities (Nirje, 1969).

Ageing is a lifelong biological process that is also socially-, historically- and culturally situated (Davidson, 2011). As a biological process, ageing involves changes in the physical body in terms of development and decline throughout life. Age and function are related in complex ways, where parallel processes make it hard to identify causality (Biggs \& Daatland, 2004). It is generally said that the risk of disability increases with age. At the same time, not all physical declines in later life are attributable to age. The conclusion that old age and functional decline do not necessarily go hand in hand is the core of Rowe and Kahn's (1997) notion of successful ageing. The idea that one could reach advanced age while maintaining a high level of physical functioning has been an important counterweight to the "decline and loss" paradigm that dominated ageing research (Minkler \& Fadem, 2000; Strawbridge, Wallhagen \& Cohen, 2002).

The experience of ageing is not limited to its bodily aspects. Ageing also occurs in the particularities of space and time and is historically and culturally situated. Although physical ageing may seem to be autonomous from societal resources, the social and material resources of a society affect survival, health, and people's life chances (Higgs \& Jones, 2009). So although ageing is a universal experience, it also occurs in diverse and dynamic contexts that include other aspects of the material world such as class, health status, gender, ethnicity and geographical location (Davidson, 2011). As individuals age, they may have different opportunities and experiences that can result in cumulative advantage or disadvantage over the lifecourse. These, in turn, may further shape the individual's concerns about future ageing.

In the papers, age and ageing are referred to in their different dimensions, sometimes emphasizing their chronological, biological, normative, or sociohistorical aspects. In Paper I for example, ageing is understood as the passage of time and the continuing process of growing old with disabilities. Past and present concerns about the body play a role in the anticipation of future care needs and future abilities to care. In Paper II, the ageing dimension is more apparent as the 
long life together in historical and biographical time and how this has shaped an experience of we-ness. In Paper III, it is emphasized that the interview participants are also chronologically old carers and that there is much care exchanged and received during later life, where risks of disabilities also increase. Lastly, in Paper IV, the relationship between successful ageing and high functioning is challenged.

\section{Disability}

Disability, like age, also has biological and social aspects. Early models defined disability as a deviation from normal functioning, and were premised on statistical models (e.g. Boorse's biostatistical model. See Nordenfelt, 1995; Davis, 2006). Such primarily bodily-based perspectives, Oliver (1990) writes, locate the "problem" of disability in the body and promote a view of disability as personal tragedy. This individual model of disability has been criticized with the development of the political activism of people with disabilities (Oliver, 1990). In British research, the shift of the locus of disability from body to society is attributed to the now cornerstone work of the Union of the Physically Impaired Against Segregation or UPIAS (1975). Their manifesto is regarded as a landmark in turning disability into a question of discriminatory attitudes and social resources over and above the functional problems of the body. Others have developed this thought further and have focused on the social creation of disability through discrimination and prejudice, forming the social model of disability (Oliver, 1990). This model represents the other end of the spectrum from the medical and bodily-centred view. It has been influential and has many strengths, but has also been criticized as too one-sided. Shakespeare and Watson (2001) and Shakespeare (2006), among others, have criticized the social model by pointing out that other tangible aspects of disability, such as pain, cannot be understood as a social consequence. Instead, they advocate understanding disability as an interaction between individual and structural factors.

In the meantime, Nordic researchers were early to conceptualize disability as the interaction between the body and the social environment, a model often referred to as the Nordic relational model of disability (Shakespeare, 2004; Tøssebro, 2010; Goodley, 2011). Nordic disability studies evolved in the context of welfare and were influenced by the principle of normalization that appeared in the 1960s (Nirje, 1969; Goodley, 2011). Normalization developed in parallel with the deinstitutionalization of people with intellectual disabilities and suggested that people with disabilities should have the same life opportunities as other people in their culture (Söder, 2003). Instead of concentrating on individuals' actual abilities, the relational model of disability looks at the social and environmental conditions that allow or restrict activity (Gustavsson, 2004). Tøssebro (2010) thus quotes Lie in calling the relational model a "participation-based" view of disability. This model also allows policymakers and practitioners to understand 
how welfare and support services could have positive effects for people with disabilities.

It is in light of disability's placement at the intersection of biological and social dimensions and where the weight of the discussion is put, that conceptual distinctions also arise. Impairment and disability is one such distinction. The social model, for example, is premised on the conceptual separation between bodily restrictions (impairment) and their negative social effects (disability) (see Oliver, 1990). An earlier model used by the World Health Organization (WHO), the International Classification of Impairments, Disability and Handicap, also relied on such a distinction but labelled the social effects of disability as handicaps (see Tøssebro, 2010). The more recent WHO document International Classification of Functioning, Disability and Health is a revised classification that aims to incorporate functional, individual and social factors in the understanding of disablement (World Health Organization, 2001). In this document, impairment has come to mean the problem of bodily function or structure, while disability is understood as an umbrella term covering impairments as well as their effects on limiting activity and participation, which may have environmental or physical explanations. Handicap, on the other hand, has become a politically incorrect term (Tøssebro, 2010).

The ontology of disability is a topic that branches into medical sociology and has different repercussions for interpreting the causes of participation limitations and social disadvantage (Thomas, 2004). Through the lens of ageing and later life, these conceptual distinctions can call attention to how increasing participation restrictions in old age are often "normalized" through the ageing body, rather than being attributed to structural hinders to full social participation.

There are also other ways of looking at how disability is defined. These definitions, rather than focusing on the ontology of disability, are based on which different groups "people with disabilities" could be. For instance, Barron et al. (2000) as well as Grönvik (2009) distinguish between an administrative definition of disability (that is useful in formulating criteria for support entitlements) and an individual definition that is self-reported and subjective. How disability is defined along these lines also has an impact in how results of different analyses of living conditions are interpreted (Grönvik, 2009).

This thesis does not pay close attention to the conceptual distinctions of disability, though I do acknowledge that biological, social, bureaucratic and subjective definitions exist in parallel. In practice, different meanings of disability co-exist, shed light on different dimensions of the disability experience, and may be hard to use in a consistent way (Grönvik, 2007, 2009). In this study, interview participants were likewise able to frame themselves in various ways in relation to disability. The weight of the discussion could for instance shift between individual or social aspects of disability. 
Different terms have been used in the papers. Sometimes these have been consciously chosen to emphasize various aspects of disability. For example, the focus could be on the disability trajectory, the long life with disabilities or the kinds of disabilities. I have used: "couples ageing with disabilities" and "disabled couples" (Paper I); "partners that have lived with disability and/or chronic illness for a long period of time" (Paper II); "couples with physical disabilities" and "spouses with long-term disabilities" (Paper III) and "older couples with longterm disabilities" (Paper IV). As a general term, both "disabled people" and "people with disabilities" are used.

\section{Care}

Care was touched on in Chapter 2, considering how caring had been delineated from other forms of reciprocity such as personal service. It was mentioned that care is typically defined as tasks performed for people who cannot manage to do these tasks themselves (Wærness, 1996). However, conclusions about the nature and effects of caring - just like in the case of disability - are dependent on which dimensions and activities researchers choose to consider (see Thomas, 1993).

On the broadest level, caring is defined as both an ethical disposition and "a species of activity that includes everything that we do to maintain, continue, and repair our 'world' so we can live in it as well as possible" (Tronto, 1993, p. 103). With this view, many of the activities in everyday life could be considered as caring. In practical terms, however, weight is often placed on the actual tasks of providing help. A more delimited view of care work-for example in elder care-is to see dimensions that concern assessing, managing and handling the frail body, or what Twigg (2000) calls "bodywork". She says that care for older people involves physical and intimate aspects often perceived by others as "dirty work", such as help with eating, going to the toilet, bathing and showering.

Care-even formal care-also inherently has an emotional dimension. The concept of "emotional labour" - managing one's own and others' emotions while doing one's job-is attributed to Hochschild but has been used by others in the context of care work (James, 1992). In informal caring, these physical and emotional dimensions mean that care could involve a variety of different tasks ranging from help with activities of daily living (ADLs), to empathy, surveillance, and stimulation (Nordberg, 2007). When informal- and family carers themselves define the help they give to others, subtle tasks such as "keeping an eye on" and "keeping company" appear to be the most frequent types of care given (Jeppsson Grassman, 2001; Jeppsson Grassman, 2003; Jegermalm, 2006). This reflects the fact that although caring is often understood as a finite and instrumental activity, it is not inseparable from a relational context (Nolan, Grant \& Keady, 1996). Focus on care as merely instrumental may also obscure other time-consuming and important aspects of care where no actual activity takes place, such as planning, worrying, anticipating and assessing the 
quality of care (McKie et al., 2002).

Another distinction relevant here is that between formal care and informal care. Formal care is that which is provided through public- and market sectors, while informal care mainly takes place in the family or the voluntary sector (Szebehely, 2005; Ngan, 2011). Other ways of seeing this may be in terms of paid or unpaid care work, although policies may blur this cash and care divide, for instance when employing relatives (Glendinning \& Kemp, 2006). The usual way of understanding the relationship between formal and informal care has been in terms of substitution or complementarity (Daatland \& Herlofsson, 2001; Johansson et al., 2003). Complementarity suggests that formal and informal support sources provide different types of help, while substitution implies that family care decreases when the volume of formal care increases. However, the relationship between formal and informal care may be more complex, and substitution and complementarity are often blurred or overlap (Daatland \& Herlofsson, 2001). 


\section{Methodology and methodological considerations}

In this section I describe the study design and methods of data generation and analysis that form the basis of my study. I also discuss the methodological and ethical considerations that have appeared throughout my work.

\section{Study design}

For this study, an explorative and qualitative design was used. Since there is little research about the ageing and caring of couples with disabilities, this kind of explorative design seemed appropriate. Explorative research, Stebbins (2001) writes, is used when researchers "have little or no scientific knowledge about the group, process, activity, or situation they want to examine but nevertheless have reason to believe it contains elements worth discovering" (p. 6). Stebbins contrasts exploratory research with confirmatory research that emphasizes the correctness of procedures and aims at hypothesis-testing or model-building. Instead, the emphasis of exploration is on understanding through the creation of new and inductively derived generalizations about the little-known group or phenomenon (Stebbins, 2001). This approach is in congruence with the tools of grounded theory methodology that I have used, which are described later in this chapter.

Exploration is not synonymous with qualitative research. The former is an approach emphasizing the generation of explanations from data, while the latter describes methodology and the actual gathering of data from which analysis is developed (Stebbins, 2001). As part of my study design, I collected data through conjoint interviews. Conjoint interviewing means that the interviews were conducted with each couple together, as a dyad. This is also described in more detail later in this chapter.

For the interviews, I used a semi-structured interview guide (see Appendix). This written guide was used to cover general themes of interest, but both the participants and I were also free to discuss related themes and issues during the interview. In 2009, before the actual data collection for the study took place, I conducted a pilot interview. This interview gave me the opportunity to 
test the flow of my interview guide and to try conjoint interviewing before actually meeting and interviewing my study participants. The pilot interview was conducted with an older married couple who shared an apartment in an assisted living facility. ${ }^{3}$ I had met this couple through a city administrator for services for older people. Some of the interview questions were revised after the pilot interview so they were more appropriate to the study participants' own situations, and for clarity.

\section{Study participants}

The study participants were older couples where both partners had had longterm or lifelong disabilities. The study group was appropriate for the aim of illuminating the experiences of families ageing and caring with disabilities. In recruiting participants, I initially set the participant criteria to include couples aged 55 and over, of whom both had lived with disabilities or chronic illnesses for a long period of time (by the participants' own definition).

I recruited the participating couples through disability organizations in southeastern Sweden, but also through contacts from local habilitation centres and through snowball sampling. The majority of the respondents were recruited through the disability organizations. Here, I first introduced myself and the aim of the project to the contact persons, and asked for their help to distribute an information letter about the project. Couples interested in participating in the study contacted me directly or provided their contact information so that they could be contacted. I had to call one couple, both with visual impairments, to inform them of the study by telephone. They were given time to decide among themselves before being contacted again about whether or not they wanted to participate. Nine older couples (18 individuals) that fit the participant criteria agreed to participate. At least three other couples were contacted who initially showed interest in the study but later decided not to participate. One widow volunteered to be interviewed but did not fulfil the sampling criteria as her husband had passed away.

I initially set the criteria for "old age" at 55 years since I was unsure if I could find an older population, but got a sample that consisted of individuals between 60 and 83 years old (in the year 2010). The 18 individual participants varied with regard to their disability and how long they had lived with disability, but in common among them was that they had lived with a physical disability or disabling chronic illness for the previous 12 years. Some had congenital conditions, while others had acquired illness or disability in youth or middle age.

\footnotetext{
${ }^{3}$ Residents living in this assisted living facility had gone through a needs assessment process. Both participants in the pilot interview had had physical disabilities that they primarily attributed to their high age.
} 
The participants experienced disabilities related to cerebral palsy (CP), Parkinson's disease, rheumatoid arthritis, stroke, loss of sight due to childhood diabetes, hearing loss, chronic pain, multiple sclerosis (MS), polio, immunological, genetic or congenital conditions, and impairments resulting from accidents. They did not consider any of these disabilities to be age-related, but many also reported age-related disabilities such as heart conditions or hearing impairments. Some reported complications were attributed to the primary illness. Examples of these were post-polio effects, respiratory difficulties for those with congenital and chronic conditions and having more extensive mobility impairments from degenerative disabilities. Three identified themselves as having at least two primary disabilities, including one participant with Asperger syndrome. At the time of the interview, the interviewed partners had been living together from between four to 45 years and thus had been living with the practical implications of disabilities for varying periods of time, but some for almost half of their lives.

\section{Implications of interview sampling}

There are some methodological considerations with regard to interview size and sampling. First, from the beginning of the study, I was not expecting a large interview group. Because of ethical considerations about confidentiality discussed later on in this chapter, this also led to my decision to interview the couples together as dyads. To maintain confidentiality, I also chose not to show information on the participants in the form of a table, as this might lead to identification.

As for the sample size, scholars point out that the number of participants should depend on the purpose of the research, but that it is contingent on time and resources. In many cases, qualitative studies may benefit from fewer interviews, with more time invested in analysis (Kvale \& Brinkmann, 2009). A criticism of a small sample on the other hand, is the difficulty of generalizing from a small group. This issue, however, depends on one's view of the need for generalizability, and what level of generalizability is aimed for. According to Kvale and Brinkmann (2009), researchers could instead ask "whether the knowledge produced in a specific interview context may be transferred to other relevant situations", rather than aiming for broad generalizability (p. 262). They present three forms of generalization based on the work of Stake: naturalistic, statistical and analytical generalizations. In this study, the results from a selfselected sample cannot be generalized for a bigger population from a statistical form of generalization. However, analytical generalizations, where one situation can be used as a guide for understanding others, can still be made. This was also done, for example, in the process of constant comparison between interviews and in the generation of concepts. 
A second methodological consideration comes from the fact that most of the participants were recruited through disability organizations. As described later in the section Ethical Considerations, this presents some problems regarding how to maintain confidentiality. It also raises the question of how interview participants choose to represent themselves, since they came from an interest organization. In Sweden, disability organizations have been strongly involved as consultative partners in the development of disability policy (Clevnert \& Johansson, 2007). A possibility is that interview participants would draw from these political and collective histories or talk from a "disability identity" when sharing their personal experiences of care (see Holme, 2013). In this respect, I agree with Holstein and Gubrium's (1995) position of seeing such narratives as a part of the stock knowledge from which the participants draw. This stock knowledge, Holstein and Gubrium maintain, comes from the participants' experiences in different social roles. They write that "the respondent's stock knowledge can shift about in the course of the interview in relation to the role taken by the respondent" (p. 30) but that "the active respondent constructs his or her experiential history as the interview unfolds, in collaboration with the active interviewer" (p. 32). In the papers, I have tried to account for the participants' stories of disability identity, but have tried to turn these into resources for the analysis rather than considering them a potential problem for objectivity. For example in Paper II, I showed that membership in disability organizations was also a shared historical background for the couple, which helped form their common identity, in addition to being spouses. Nevertheless, more important than their relative homogeneity as belonging to a group, the participants displayed heterogeneity in terms of types and degrees of disability, as well as degree of need for help. The participants had also had different life opportunities because of these factors, showing how people with disabilities are far from a homogenous group. Since the time of disability varied for the participants, this also affected the couples' shared lives in different ways.

A third and related consideration is the fact that the participants were recruited into the study knowing that they would be interviewed together, which may also have influenced the interview narratives. Furthermore, as in other studies where informants themselves choose to be included, there might be some participant bias, with couples that see themselves in well-functioning relationships being more likely to participate. These factors of course, shape my own results. I have tried to account for these, for example in acknowledging that we-ness could be understood both as an interview effect and as a research result (Paper II). Paper II goes into these methodological issues in more detail, but I also argue there that although the dyadic data undoubtedly shapes the results, it has also contributed to the richness of the analysis in other ways that may not have been possible through individual interviews. 


\section{Conjoint interviewing}

Interviewing as pairs, so called dyadic interviewing, has been used as an alternative to individual interviews for the last 30-40 years (Allan, 1980; Bennet \& McAvity, 1994; Arskey, 1996). It is a kind of group interview that is directed at naturally occurring pairs, in contrast to focus groups that rely on ad hoc groups of people that might not have previously known each other (Morgan, 1996; Hydén \& Bülow, 2003). Generally, the term dyadic interview refers to any interview method involving dyads as the unit of data collection and analysis. Besides couples, examples of other pairs interviewed as dyads are best friends and sisters (Mauthner, 2000; Rosenblum, 2000). Dyads can also be interviewed together, separately but simultaneously, or separately on different occasions (Eisikovits \& Koren, 2010). Conjoint interviews, sometimes called "joint interviews", refer specifically to dyadic interviews where the pair is interviewed simultaneously in the same interview situation.

In dyadic interview methods, the pre-existing relationship between the interviewed dyad is a premise rather than a contingency. Conjoint interviewing of couples has been used in the social sciences to gain a shared or "weperspective" on mutual or family experiences. In these interviews, the shared story, but also how individual members express themselves about the same experience, is something that permeates the study design and analysis (S.M. Morris, 2001; Eisikovits \& Koren, 2010). Of particular value to this research is that conjoint interview methods have been found useful in producing rich data on couples' experiences of illness and caregiving, especially in later life (Racher, Kaufert \& Havens, 2000; van Ness, Runge \& Jonsson, 2009; Molyneaux, Butchard, Simpson \& Murray, 2011).

The ethical consideration of possibly provoking negative feelings towards dependence or unwilling caregiving was the main reason I decided against interviewing couples separately, as it would be hard in the written work to make the identity of informants unknown to one's partner (see the section Ethical Considerations later in this chapter). That said, interviewing couples also has the advantage of allowing a common story to emerge. Furthermore, as Allan (1980) notes, the actual interaction in the interview constitutes data not easily obtainable through other methods. This interactive data and the possibility for the dyad to confirm and correct each other can make the analysis richer by broadening the range of experiences that can be compared (Allan, 1980). Of course, there may be instances of imbalance of power in such interactions, for instance when one partner talks more than other, or takes over. In this respect, I have also taken steps in the interviews to try to give equal voice to the participants. But needless to say, conjoint interviewing has disadvantages and advantages, just like other methods.

I conducted the first round of interviews in 2010. The interviews were between two to three hours long and were carried out mostly in the couples' 
homes (except in one case, where it was conducted on the university premises). The interview guide explored themes such as: own disability, how the couples met, everyday life with disabilities, the kinds of support they provide for each other, other sources of help and support, and ageing together with disabilities (see Appendix). As is the usual practice, the material was tape-recorded with the participants' permission and transcribed verbatim for analysis. In the transcriptions, names of persons were changed.

Regarding the disadvantages of the interview method, I can mention the challenge of doing justice to both partners' stories and voices in a limited amount of time. Although I was interested in their common story as a couple, the individual stories of disablement were also important and helpful for understanding their view on help and care. Another challenge of interviewing the couples together was urging them to find expression for what they might see as commonplace experiences. Helping and caring for each other often seemed intertwined with "just" living together. This problem was addressed by asking about specific activities around the home, or specific things that they needed help with. Because the individual respondents' disabilities and their levels of need for help and care were different, it was hard to formulate generalized questions regarding types of help. These types of questions thus varied from interview to interview. At first, respondents may think that they require very little help, but their answers to questions about daily activities such as "What is a normal day like?", "What do you do after the personal assistants go home?", "Who does the shopping?" or "Are there chores that one can do that the other cannot?" indicated that they also helped each other frequently.

As the analysis of the first round of interviews progressed, I decided to conduct follow-up interviews with some of the couples. At the start of the project, I did not plan to conduct complementary interviews. However, as I analysed the aspect of change over time, I wondered what might have happened to the interview participants, in terms of changes in care needs and care provided, after two years. Because the initial conditions for participating in the study did not involve agreeing to be interviewed a second time, I formulated my information letter in 2012 as an invitation for a follow-up interview. Four couples agreed to be interviewed in the second round of data collection. The couples who did not agree to be interviewed were not asked to give reasons for not wanting to participate. One of the participants had become a widow, and one couple did not reply to the invitation.

The second round of interviews was not based on theoretical sampling in the original sense since no new sampling criteria were formed (see Glaser \& Strauss, 1967). However, in the same way as theoretical sampling, these interviews made it possible for me to delve deeper into aspects of age and change that had started to appear in my earlier analysis (Corbin \& Strauss, 2008). These interviews also allowed me to ask what these changes over time involved, now 
that we had a common point of reference back in time. Indeed, it turned out that the two years between interviews involved different changes in the couples' situations. Many of these life changes were related to increased disability and increased care needs. In 2012, two of the four couples interviewed had moved to disability-adapted homes that were closer to basic services and home help services. The participants' changing physical conditions (which had improved in specific aspects, but also generally worsened with age) had also brought about changes to their social life and participation in activities. However, stories of shrinking social participation and opportunities for activity were also countered by stories where the couples could be interpreted as maintaining their usual activity, if not even increasing other types of activities. I made similar observations in the 2010 interviews of how the couples talked about themselves as advantaged and active despite worsening disabilities and a more limited life. Together with a co-author, I developed these themes in Paper IV and set these observations against the notion of successful ageing that takes high physical functioning as a prerequisite.

\section{Analysis methods}

To analyse the interview material, I used coding and constant comparison, which are tools that originate from grounded theory research but are also used as general analysis methods in the social sciences (Taylor \& Bogdan, 1998). The aim of using these analytical tools is to systematically produce inductively derived generalizations about the phenomenon under study (Stebbins, 2001). This encourages exploration and understanding about a phenomenon that has not yet been widely researched, instead of trying to comprehend the data using already established concepts.

Grounded theory is a research method that was first developed by Glaser and Strauss (1967). It emerged as a reaction to the dominance of quantitative social research and the tendencies of qualitative research to confirm "grand theories". By laying out a set of tools for data investigation, they showed how qualitative analysis could not only be robust and grounded in data, but also provide a framework for theory-building. Following this method means constructing codes and categories from close reading of the data. The differences and similarities in the data are constantly reviewed and compared against one another to challenge, revise or explore emerging categories. At the same time, as these concepts and categories are linked and explained in relation to one another, the aim of the analysis is to give the emerging theory explanatory power (Charmaz, 2006). The aim of the method is to capture difference, complexity and nuance, while trying to explain a phenomenon in theoretical terms. The method is also compatible with an explorative design. Maintaining flexibility and openness during the interviews and in the analysis, instead of applying set concepts such as "carer" and "caregiver", allowed me to be open to different 
expressions of what care could be in the couples' stories and develop these without undermining the participants' own role as actors in concretizing and giving meaning, to care.

Grounded theory has been criticized for having positivistic undertones of using a rigid set of methods for discovering something hidden in the data (see Charmaz, 2006; Salminen-Karlsson, 2002; Clarke, 2005). Underlying this criticism is the methodological dilemma of claiming closeness to the data, while also constructing one's own interpretative frame. Later versions of grounded theory have a more constructivist approach (Mills, Bonner \& Francis, 2006; Bryant \& Charmaz 2007b; Corbin \& Strauss, 2008). My epistemological standpoint leans towards these constructivist variants of grounded theory that recognize the role of the researcher as the interpreter of the data, and acknowledge that the conceptual analysis of the author, although grounded in the participants' stories, is an interpretation. In focused coding, for example, I made decisions on what and what not to focus on.

It is also important to note that grounded theory perhaps can no longer be described as a single method, but rather as a set of tools for analysis. Grounded theory is sometimes described as a "family of methods" (Bryant \& Charmaz, 2007a, p. 11) and "as a set of principles and practices, not as prescriptions or packages" (Charmaz, 2006, p. 9). Throughout my analysis process, I used the tools of grounded theory methods to raise the material from a descriptive level to a set of concepts. These tools - coding and constant comparison-consist of "the most basic operations which provide the basis for category building" in grounded theory methodology (Kelle, 2007, p. 193).

\section{Coding and constant comparison}

Coding makes up the bones of the analysis (Charmaz, 2006, p. 45). Its initial stages are open and spontaneous, as the researcher tries to maintain curiosity but remain within the frames of the general research interest. In this open coding, the researcher, through naming small sets of data-often at a line-by-line leveldefines what she sees as significant or what she thinks the data is about. Codes give names or labels to specific events and observations in the data. For instance, I interpreted the data and decided that a set of descriptions and expressions by the interview participants represented the phenomenon "practical problems" or "worrying". I have also used in-vivo codes, which are codes that borrow the participants' own words to get a feel for the phenomenon being described, such as "being right in it" or "being two". The coding process often results in a large number of codes, of which some are more theoretically interesting than others and better lend themselves to conceptual development.

In practical terms, as I developed my articles close to-or sometimes simultaneously with - the analysis process, this has implied making decisions on what to analyse further. This is what could be described as focused coding, which 
is a more selective phase of coding in which the aim is to synthesize and explain larger sets of data (Charmaz, 2006). For instance, I looked at a certain set of related codes pertaining to time (Paper I), language (Paper II), the relation between formal and informal help (Paper III), and active ageing (Paper IV) in my work. Some codes become subsumed into other codes, or larger sets of categories, that are labels for related events in the data that have some explanatory power (Corbin \& Strauss, 2008). This type of categorization can be seen most clearly in Paper III, where the categories Mutual care as freedom and Mutual care as imperative were fleshed out using subcategories.

The analysis process is never linear, but is fluid and develops continuously, for example through constant comparison between codes and data sets. Constant comparison is the process of making analytical comparisons with the aim of finding conceptually similar incidents in the data (Corbin \& Strauss, 2008). Doing this allows the researcher to move analysis from a level of description and single cases, to a level of abstraction that can help illuminate other cases. Dyadic data such as that produced in my interviews present further possibilities for making comparisons. One could, for instance, compare incidents in the same interview, at the level of the couple, or between different couples (see Boeije, 2002). It is through the process of coding and constant comparison between different levels of data that I developed concepts such as equilibrium in Paper I and we-talk in Paper II. In Paper III, comparisons of the various ways care could be seen as an imperative resulted in its subcategories. Likewise, it is through the comparison of the interview data that we were able to identify the couples' different resources for advantageous and active ageing in Paper IV.

In my analysis, theoretical comparisons (Corbin \& Strauss, 2008) where properties of the data are compared using elements and insights from experience or "from the outside" were also important to reach a level of abstraction beyond specific cases. The couples, although all ageing with disabilities, were varied in their level of function and degree of care needs. Although a small group, they also represented a broad range of different experiences. For example, one couple needed to help each other in doing a household chore, because both of them were unable to do this alone. Another couple instead seemed to resemble a typical carer and care receiver dyad. A third couple had varying disabilities and needed different types and intensities of help at different times. A fourth couple believed they needed no help, but managed on their own through mutual helping. To understand what is common between these incidents, other properties and concepts to guide analysis, such as reciprocity and family roles, are helpful.

A common issue in using grounded theory methods is that coding is very time-consuming (Wells, 1995; Backman \& Kyngäs, 1999). Another and more serious criticism is that grounded theory can only lead to understanding and insight, but not to real explanation as often claimed by grounded theorists themselves (Thomas \& James, 2006). This view is critical of grounded theorists' 
claims of discovery, arguing that interpretations made through grounded theory research may be no different from interpretations in general, as a hermeneutic act. The underlying issue here is whether grounded theory methodology could (or should) generate theory. Followers of grounded theory are themselves divided on whether the result of grounded theory-based analyses should lead to sensitizing concepts, core categories, substantive theory, or formal theory (see e.g. Clarke, 2005). With regard to this issue, I see this thesis as a product of a grounded theory process, and I take the view of research as "producing input into the social dialogue rather than generating ultimate and unequivocally verified knowledge" (Flyvbjerg, 2001, in Kvale \& Brinkmann, 2009, p. 257). I also agree with Adele Clarke on the impossibility of constructing a terminal formal theory. Rather, in this study, I sought to develop what Clarke calls "sensitizing concepts" that are nonetheless grounded in the data (Clarke, 2005, p. 28). The concepts and categories that I have developed in this research can be used by others, or developed further.

\section{Research validity}

The concept of research validity developed from a quantitative and experimental research tradition but was adapted by the qualitative research community due to criticism that qualitative research lacked "standard" means to ensure trustworthiness of results (Maxwell, 1992; Seale, 1999). Underlying this issue is the question of whether there are means to assess the legitimacy of the results taken from interviews or observations. This issue becomes especially relevant in a post-modern context where it is acknowledged that the researcher is the coconstructor and interpreter of the data.

The different purposes and natures of qualitative and quantitative research, according to a number of scholars, make conventional criteria for validity irrelevant and often inapplicable to qualitative and exploratory studies (Krefting, 1991; Stebbins, 2001). In past decades, this has resulted in the development of new sets of criteria to assess validity in qualitative research (e.g. Lincoln and Guba, 1985). Others point out, however, that the same set of criteria may not even be applicable to different types of qualitative research, since qualitative studies usually rely on different sets of data and different analysis methods (Krefting, 1991). Defining validity from a set of recommended procedures also seems rather positivist (Maxwell, 1992; Seale, 1999) and overlooks the fact that qualitative research is inherently iterative and has the character of creative work (see Morse, Barrett, Mayan, Olson \& Spiers, 2002; Kvale \& Brinkmann, 2009).

However, defining validity in terms of procedures is not the only approach available. Maxwell (1992) suggests a realist typology of the validity, based on how qualitative researchers tend to think about this issue. I have found his typology useful in conceptualizing validity at different stages of the analysis. Like Morse et al.'s (2002) and Kvale and Brinkmann's (2009) perspectives, 
Maxwell (1992) regards validity as part of the research process itself, rather than merely a separate stage at the end of the work. He stresses, in regard to the personal accounts of subject participants, that validity "does not depend on the existence of some absolute truth or reality to which an account can be compared" (p. 283). Rather, "validity pertains to the kinds of understanding that accounts can embody" (p. 284) or what the researcher claims the account is about. Maxwell also shows how it is possible for others to resolve issues of trustworthiness on different levels.

The first type of validity described by Maxwell is descriptive validity. This type of validity has to do with the factual accuracy of the accounts, and how to make sure that what the researcher describes is not a fabrication. This meaning of validity becomes relevant when recounting interview data or when describing details concerning interviews and observations. In interview studies such as this one, interview transcriptions are an important element in ensuring descriptive validity. Already when I transcribed the data, I could compare if my memory of the account corresponded to what was actually said in the interviews. In writing the papers, I also regularly re-read the transcriptions to check that general statements about what participants had said actually had grounds in the empirical material. Issues on this type of validity, according to Maxwell (1992), are the easiest to resolve, given the appropriate data. Regarding this study, it should be easy for a third party to audit my descriptions of the interviews and the cited interview material with the help of my transcriptions. But descriptive validity, Maxwell writes, also deals with omission and commission of accounts. For example, it would be improper for a researcher to omit parts of the accounts that seemed relevant for the participants for the purpose of focusing on an issue. In this respect, it is important for the study's overall validity to keep a critical eye on one's own developing analysis and to check for sources of invalidity, for example, by giving a balanced description of the account (Kvale \& Brinkmann, 2009).

When making claims about what accounts mean for participants-for example during the process of coding described earlier in this chapter-another type of validity can become an issue. Here, the weight is no longer on the valid description of the account, but rather on the credibility of what the researcher describes as "the participants' perspective" (Maxwell, 1992, p. 288). Maxwell calls this type of validity interpretive validity. According to Morse et al. (2002), wellgrounded qualitative analyses are somewhat self-correcting on this point. By moving back and forth between data and analysis, they argue, interpretations can develop a fit with the data. Indeed, the appeal of using grounded theory methods is its goal of sticking as closely to the data as possible when developing analytical codes and categories. In this study, this means that the codes and categories that survived in the analysis - those that I have developed in the different paperscould be traced back to different instances in the interviews. For instance, in 
Paper IV, we claim that participants saw themselves as having "an advantaged ageing" despite worsening disabilities. Although I had noticed this theme from the 2010 interviews, what supported this claim was our observations in the interview text of participants describing their ageing as more positive compared to other groups. Maxwell underlines that this type of validity should not be seen as correspondence between interpretation and some kind of objective truth. Rather, interpretive validity rests on an idea that "any valid account or explanation of a social situation must respect the perspectives of the actors in that situation, although it need not be centered on that perspective" (Maxwell, 1992, p. 290).

A third type of validity is what Maxwell calls theoretical validity. Concerns about this type of validity, according to Maxwell, cannot be resolved by merely going back to facts in the empirical material, because the claims made have a higher degree of abstraction. Rather, this type of validity is concerned with the credibility of the researcher's explanations of the phenomenon. On the one hand, it deals with the appropriateness of the concepts employed. On the other hand, in building an analysis, concepts are also strung together to form a coherent account that could itself be more or less sound. Here, I here agree with Reissman (1993) who says that the results of qualitative studies are analytical interpretations whose aim is credibility and not certitude. My interpretations have of course been formed through-and with the help of-my own experiences and past knowledge (see Corbin \& Strauss, 2008). Shared methodological and theoretical perspectives in the research program, such as the lifecourse approach described in Chapter 2, have also shaped how I interpreted my data and formed my analysis. However, I also agree with Kvale and Brinkmann's (2009) view that one should always strive to have well-grounded and justifiable arguments in creating defensible knowledge claims. On this level, I believe that citing interviews and describing interview accounts in the written text are important when demonstrating a concept or strengthening an argument, in order for these to be convincing. Perspectives of other researchers, for instance the peer-reviewers that have read my texts, have also been important checks in my work to ensure that my explanations are robust enough and comprehensible to others.

\section{Ethical considerations}

Besides methodological considerations, social science research on the experiences of individuals also requires ethical considerations. These considerations may concern how sensitive or identifying information is treated, the researcher's own attitudes towards (and just representation of) the participants, and respecting the participants' autonomy through acquiring informed consent and assuring them of the possibility to withdraw from the study at any time. Ethical approval from a Regional Board was not necessary for this study according to the 2003 Act on Ethical Review for Research Involving Humans (SFS 2003:460). Nevertheless, 
because all research risks encroaching on people's lives and integrity, awareness of moral principles and moral reasoning about decisions made during the study is important (Kjellström, Ross \& Frilund, 2010).

Basic moral principles express the underlying values and rules in common morality, and function as guidelines or frameworks for professional ethics (Beauchamp \& Childress, 2001). Beauchamp and Childress identify four such clusters of moral principles: respect for autonomy (respecting the decision-making capacity of autonomous persons), nonmaleficence (avoidance of doing harm), beneficence (balancing benefits against risks), and justice (distributing benefits and risks). These basic principles are also operationalized in written guidelines and rules for conducting research. In writing this study, I have referred to published resources on how to conduct ethically sound research available through the Swedish Research Council (2002, 2011). Besides a research criterion (the justifiability and the quality of the research contribution), the Council stipulates a criterion for the protection of individuals, which embraces other requirements such as informed consent, confidentiality and restrictions on re-use of data. These guidelines were followed throughout the study. For instance, an information letter was used, personal details in the transcripts were changed, and the couples were not asked for their reasons for not participating in the first or second round of interviews. With regard to the safekeeping of data, all sound files from the interviews and their transcripts are kept in a locked drawer in the institution, such that they are not accessible to unauthorized persons.

Throughout the research process, however, I also encountered situations that required balancing benefits with risks, such as when research design and writing could run the risk of encroaching on the participants' integrity in different ways. Such dilemmas require moral reasoning, especially since not all issues are covered by research guidelines. Below I describe some of these dilemmas and the decisions I have taken. These cases also highlight that adherence to moral principles of respect of autonomy, nonmaleficence, beneficence and justice is almost always a matter of balance and judgment (Beauchamp \& Childress, 2001).

One of my main ethical considerations appeared early in the process, regarding study design. Because of my intended focus to study care in the context of couples where both partners have long-term disabilities, I was not expecting a large interview sample. My dilemma was that questions on couplehood and care had a risk of eventually leading to sensitive answers about conflict and friction between the caregiver and care receiver. If interviewed as individuals, it would have been hard in the written work to conceal the identity of participants from their partners. Because of this dilemma, I chose a study design where couples were interviewed together conjointly. This gave the opportunity for a shared and consensual story to emerge, but also gave the partners opportunities to negate and negotiate. The decision to interview the 
couples as dyads, of course, also leads to other methodological and ethical considerations. For instance, there can be the problem of imbalance of voice and power, problems of disclosure when the other partner listens, and what might be thought of as pressure on the couple to present a positive, rather than a problematic, picture of their relationship (see S.M. Morris, 2001; Forbat \& Henderson, 2003; Taylor \& de Vocht, 2011). There is also an added dimension to informed consent when interviewing conjointly, since if one partner refuses to be interviewed, the couple cannot be interviewed (Racher et al., 2000; Forbat \& Henderson 2003). Some of these concerns were touched upon in Paper II, even if the focus there was on methodological (and not ethical) implications of conjoint interviewing.

One other important consideration that appeared in the interviews but was only partially touched upon in the papers, was the subtle ways in which issues of voice and power can appear in the interview situation. This meant, for example, respecting limits regarding what the informants did not want to talk about (even if information might be potentially interesting); trying to direct questions to both partners and allowing an equal opportunity for them to answer (especially in the case of those with communication or hearing difficulties); and creating a balance between empathic listening and steering the interview conversation towards a focus.

Later in the interview and writing process, I also reflected upon the implications of the sampling methods (where participants came from closed groups that often knew each other) in regard to the confidentiality of the participants. In one interview, it was apparent that one couple knew that their friends were also being interviewed. Full confidentiality is not possible in such cases, but this made me consider what information to disclose in the text, and if there were alternative ways of presenting information. What I chose to do was to use alternative interview excerpts when available, if there was risk of identification. I also in some cases tried to describe the participants in other ways than the nature of their disability. Furthermore, in each of the papers, I chose to give the couples different family names, or refer to them without the use of names. 


\section{Summary of the papers}

\section{Paper I}

\section{Ageing and care among disabled couples}

Does it make sense to simultaneously be dependent on help and care in everyday life and consider oneself a caregiver? How are help and care manifested in a relationship where both have disabilities? How do ageing and disability trajectories affect the preconditions for spousal caring?

Paper I explores if and how spousal care can be understood between partners that live and age together in spite of long-term disabilities, and how preconditions of spousal caring change over time. Disability not only affects the individual, but also the family, in terms of everyday life. The background for this paper is, however, that people with disabilities largely remain "care invisible".

The results of this paper show that the everyday lives of the couples with disabilities included invisible care tasks as well as care work-despite not being "carers" in the traditional sense, or even considering their activities as care. Care work was hidden behind the everydayness of these activities, the pragmatic attitude of just making things work and the fact that these activities merged with other aspects of couplehood, such as maintaining closeness. Nonetheless, it was apparent that care in its different forms took much and space in everyday life and that care concerns extended into the future. As the couples aged with their disabilities and faced expected and unexpected changes in disability trajectory, they worried about a time when their care situation, experienced as an equilibrium, might no longer work. These worries were manifested as fears about one's health, the partners' health, but also the ability to give and provide spousal care with worsening disabilities.

The results reveal aspects of care that are usually neglected, such as that it is temporal and embodied. They also show how individual disability is a shared concern, because it affects how the couples cope with practical issues of living and caring. It is suggested that "care", understood primarily as help carried out for instrumental goals, might not be a sufficient concept to understand the extent 
of the work these couples do to maintain living and ageing together. The concept We-work is suggested, as an expression of the practical, emotional, care-related and time-related concerns associated with maintaining life together with disabilities.

\section{Paper II}

\section{Using conjoint interviews with couples that have been living with disabilities and illnesses for a long time - Implications and insights}

What are the characteristics of the data generated in the conjoint interviews? How can the resulting data contribute to understanding care in disability contexts? What are the potentials and limitations of the method?

Paper II discusses conjoint interviewing as a specific method that produces specific data, and how this method was used to investigate spousal help and care between couples with disabilities. Concrete examples from the interviews are used in this paper to illustrate the issues linked to this method. These are: the kind of data produced, how the interview method may have shaped the narratives about spousal help and care, the method's limitations, and its possibilities for creating new insights. Data production and data analysis are inherently linked. An approach that takes mutuality into account may, as a result, give other insights than if individual interviews were used.

The results of this paper show how the conjoint interviews produced what I labelled as we-talk. We-talk included stories about shared experiences and concerns, that helped create a sense of we-ness, or a sense of being a unit. In the interviews this sense of we-ness was further mentioned as a resource for caring. Consequently, we-ness could be understood as both an interview effect and an analysis result, since it is in the light of shared experiences of disability that one can further understand why instrumental care and help were given between the partners. Another finding was that conjoint interviewing produced interactive data. This interactive data revealed how disabilities can influence daily activities and communication tasks. It also revealed everyday forms of mutual aid and assistance that may have been hard to capture with individual interviews.

By including mutuality in the study design, and through not casting the spouses in pre-set roles as carers or care receivers, it is suggested that conjoint interviews can lead to new insights. It could also offer an alternative form of discussion on spousal care-one that includes people with disabilities as mutual givers and receivers of informal care. 


\section{Paper III}

\section{Freedom and imperative: Mutual care between older spouses with physical disabilities}

Why do couples experiencing physical disabilities provide different kinds of help for each other, including what may be considered as heavy care tasks, despite the existence of formal care and welfare systems aimed at them and those they care for? How does the relationship between them shape the experience of mutual caregiving?

The background for Paper III is that much of the informal care given to older people is provided by their spouses, who in their turn might also have a disability. Informal caring has often been framed as either a substitute or a complement to formal care. In Paper III, I use the interviews with the couples with disabilities to show that informal caring can have other dimensions which help us understand why mutual care is exchanged, despite practical difficulties and despite the availability of formal support. In the article, these dimensions are summarized through the categories Mutual care as freedom and Mutual care as imperative.

The results of this paper show that mutual care was not only used to provide instrumental freedom to do certain tasks, but was also used by the couples to maintain freedom from formal care and to be independent and free to be themselves as a couple. This aspect also proved to have practical implications for maintaining independence, self-care, and quality of life. However, the spousal relationship itself involves norms of how it is to act as a couple, which include caring as a "natural" part of the relationship. The category Mutual care as imperative shows how the spousal relationship shaped the experiences and expectations of mutual caregiving. Mutual caring was regarded as secure and reliable, and as an automatic "part of their lives". However, it is also experienced as a moral obligation to care and can become $a$ "job" that may be hard to live up to when one is ageing with disabilities as well.

The findings from this paper help us understand the complexity of spousal care and that is has both liberating and normative aspects. The results also show a more complex relationship between formal and informal help than merely as substitutes or complements of one another for task-specific and time-equivalent helping. Motivations for caring for a spouse stem from the pleasures, demands and the logic of the relationship itself. Both positive and negative aspects of caring for a spouse have to be considered to understand why spouses with disability continue to give help, and when caregiving can become a burden. 


\section{Paper IV}

\section{Older couples with long-term disabilities: Multiple jeopardy or successful ageing?}

How and in what respects did the couples consider themselves as advantaged, despite ageing together with disabilities? How did the couples manage to maintain a high level of activity in some areas of life, despite worsening disability in old age?

Paper IV touches on the implications of couplehood and mutual caring for the lives of the interviewed couples, who in a sense can be thought of as ageing with multiple disadvantages as they age with disabilities together. This discussion is set against the background of Rowe and Kahn's notion of successful ageing, which takes a high level of functioning as a prerequisite. This prerequisite contrasts with unexpected results from the interviews, namely how the couples talked about their ageing as advantageous and active, despite worsening disabilities and practical hardships of living together with their disabilities.

The results of the analysis show that the couples could use high age, the long life with disability, but also "being two" as a couple with disabilities in regarding themselves as ageing advantageously. They mentioned different types of resources that allowed them to age better than certain other groups, but they were also supported by social resources and technical aids to maintain active lifestyles. The continued possibilities of engaging in activities together despite reductions in their individual capacities increased the sense that the couples maintained active lifestyles.

The conclusion of this study is that the couples had the ability to use categories that could otherwise be considered as disadvantageous - such as age and disability-as positive categories, through positioning themselves in different ways as older people or as people with disabilities. These results reveal how any pre-set criteria of successful ageing could be problematic, as the couples used the very situations that would otherwise cast them as a disadvantaged group, to consider themselves as advantaged. Growing older together with longterm disabilities need not be a disadvantage in the relationship, but as a resource in ageing successfully "as a couple". 


\section{Discussion}

The aims of this thesis were to explore how care is actualized and experienced by couples that are ageing together with long-term or lifelong disabilities, and to investigate the implications of this caring in the couples' lives. The thesis was also described as being at the intersection of gerontology, care research and disability studies. As a work on social gerontology, it deals with older couples' experiences of ageing with long-term or lifelong disabilities. But the work also specifically explores mutual caring that is part of these older couples' lives. In this way, the thesis also touches on care research and disability studies. It explores informal care from the perspective of adults with disabilities, and in doing so brings a discourse of care into a disability context.

The first research question was: How is care actualized and experienced by couples that are ageing together with long-term or lifelong disabilities? The papers explored different dimensions of this question and showed how the interviewed couples provided care for each other in different ways. This care ranged from emotional support and sharing of household chores, to communicative help and physical tasks traditionally associated with care work. These activities were often embedded in everyday life (Paper I). They also occurred spontaneously (Paper II) and as a "natural" part of the relationship (Paper IV), meaning that the couples did not often regard these activities as caregiving. Nevertheless, these activities contributed to positive effects in the couples' lives (Paper III) and may have been significant for how the couples judged their quality of life as high (Paper IV).

The second research question was, What are the implications of this caring as the couples grow older with disabilities? In exploring this question, the lifecourse perspective and the concept of linked lives influenced my interpretations of what mutual caring was, and what its implications might have been in the couples' lives. Care concerns stretch through the past, present and future, and this meant that couples worried about their own future capacities to provide care (Paper I). On the other hand, mutual caring also reinforced the existing sense of we-ness between the couples (Paper II). Aspects of joy, but also of obligation, turned out to be significant in explaining why care was given to a spouse despite one's own disability (Paper III). However, being two people with disabilities and doing things together also appeared to contribute to the couples' sense of ageing successfully (Paper IV). The different papers showed how care is an inherently 
relational concept and takes on different expressions in everyday life. Care in the couples' lives flowed along the spectrum between the invisibility of everydayness to the conspicuousness of care work as " $a$ job". The implications of mutual caring, in turn, varied from maintaining couplehood (Papers I and II), to increasing independence from others (Paper III), and their quality of life as a couple (Paper IV).

In Chapter 1, I stated that there I had two ambitions for this thesis. On the one hand, I wished to understand care outside dichotomies classically used to frame it, such as non-disabled/with disability, old/young, dependence/ independence and caring/servicing. On the other hand, I also had the ambition of making an empirical contribution to gerontology, by describing a group of older people whose experiences of ageing are seldom discussed. The main findings of this thesis, as a whole, correspond to these two ambitions. First, this study can help in conceptualizing care as a dynamic activity where boundaries between carer/care receiver and caring/servicing blur and intermesh over time. This challenges traditional ways of framing certain groups as receivers and providers of care and also problematizes conventional ways of understanding the concepts of dependence and independence. Second, this study also helps to show the diversity of ageing experiences by contributing to the growing literature on ageing with disability. The group described do not consist of the usual carers; nor are they the usual successful agers. This, in turn presents a picture of affirmative old age with disability rather than the binary ways of seeing ageing in terms of either decline or success.

\section{Care as a dynamic activity}

Through recognizing other carers and exploring care through a lifecourse perspective, this study shows care as a dynamic activity. Dichotomies often used to understand care sometimes appear to be static, mutually exclusive and unidirectional. For instance, a person involved in care can either be described as the person who has help needs or the person who meets these needs. Based on what the receiver can do, reciprocal activities are categorized as either caring or servicing. It can also appear from texts on disability rights that persons with disabilities can either be independent and in control of services received, or dependent on the care of others. The first main contribution of this thesis is to show the many ways in which these dichotomies can blur when one considers care as a dynamic and embodied activity that involves different roles over time.

\section{From carer/care receiver to concurrent roles}

The background presented in Chapter 2 showed that the definition of care goes hand in hand with the conceptual demarcation of the roles of carer and care receiver. A carer is often defined as someone who provides care to a dependant, 
while a care receiver is a person who cannot perform tasks without assistance. In the absence of a time perspective, these roles appear to be unidirectional and essentialist. These social relations are built on a kind of essentialist negation, or what Shakespeare (2000a) calls "othering", since they are premised on the qualities (or inadequacies) of individuals who receive care (Shakespeare, 2000a, 2000b).

Such perspectives have been criticized for neglecting the fact that people casted in care receiver roles also provide much help and care for others (e.g. Shakespeare 2000b; J. Morris, 2001). Categorizing older carers as vulnerable groups only reinforces the ascription of "the carer role" to younger and nondisabled people. Such perspectives lack the dimension of embodiment and temporality that can reveal how all people can sometimes be carers, sometimes be care receivers, and are often both at the same time. Taking temporality into account, on the other hand, reveals how caring activities involve reciprocity of different forms of care over long timescales (Bowlby, 2012).

In gerontology, spousal care in old age is a particularly interesting example of how carer and care receiver roles can blur and overlap, since it cannot be taken for granted that a spouse providing care is in good health (Corden \& Hirst, 2011; O'Connell, Bailey \& Walker, 2003; Ahn \& Kim, 2007; Jowsey, McRae, Gillespie, Banfield \& Yen, 2013). In this study, care was provided through people whose bodies were ageing with disabilities. The embodied nature of care work was described in Papers I and III, but was most prominent in the examples of performative data described in Paper II. The dynamics of caring with disabilities also had a special character, since changes through time affect the conditions and abilities to give help from a long-term perspective (Paper I). In the couples' stories of giving and receiving care, this made it hard to draw a hard line between the roles of carer and care receiver. Understanding mutual care through the concepts We-work, equilibrium or as "part of their lives" underscores instead the blurring of these roles. As Fine and Glendinning (2005) write, the distinction between a "dependent" and "carer" may indeed be increasingly inappropriate for older people, since needs may be finely balanced between them. The conjoint interview method used in this study contributed to a certain deconstruction of carer and care receiver roles, since the method allowed the participants to frame themselves as concurrent actors in a relationship, rather than as either a carer or a receiver of care.

\section{From caring/servicing to intermeshing practices}

Over time, physical disability can involve changes in physical capacity, changes in the ability to participate in meaningful activities (Paper IV) or changes in the ability to provide care for a partner (Paper I). With regard to the concept of care, the predictable and unpredictable changes that affect one's different abilities could also challenge traditional distinctions between "personal service" and 
"caring". The distinction between caring and personal service has been based on whether the care receiver could manage to perform tasks without assistance (Wærness, 1996; Leira \& Saracendo, 2002). However, looking at partners that both have disabilities begs the question of whether it makes sense to ask when servicing crosses over to care, or caring crosses over to servicing. The results of this thesis show that while helping was part of the everyday delegation of tasks, these tasks could sometimes be difficult to perform due to changing health, unexpected problems, or sudden tiredness (Papers I \& III). In this way, caring and servicing could become intertwined in the couples' everyday lives because the partner's ability is not always easy to establish when personal help and help with tasks are exchanged on an everyday basis.

The distinction between caring and servicing that builds primarily on ability/disability is also not enough to understand some of the examples in the thesis where caring and servicing appear to intermesh. In Paper III, some of the participants gave their partners help with care tasks that otherwise would be provided by personal assistants, such as dressing, cooking, transport or help with eating, but they tended to see this as a service because the partner had the possibility to have these needs met in other ways. Conversely, some activities that appeared to be natural elements in family life, such as listening to music together or taking walks, had the character of care since they increased the partner's participation and quality of life, fulfilling needs that might otherwise not have been met. Focus on care as merely instrumental help for someone that cannot do things himself, according to other scholars, may also obscure other time-consuming and important aspects of care where no actual activity takes place, such as planning, worrying, anticipating, and assessing the quality of care (McKie et al., 2002). This shows that the distinction between caring and servicing is problematic in other ways, as it can only account for care in the form of actual activities of instrumental help.

\section{From dependence/independence to interdependence}

As mentioned earlier (see Chapter 2), disability writers criticize how care literature underlies assumptions of care receivers as dependent care burdens (J. Morris, 1997; 2001; Shakespeare, 2000a; 2000b). Care is often defined from the basis of physical dependency. Yet, as pointed out by these disability writers, independence does not merely mean being able to do things oneself. Here, there is an important difference between physical dependency on help from others, and a social dependency that results from typecasting people with disabilities as a burden (Shakespeare, 2000b). Disability writers have argued that independence should be understood in relation to social dependency rather than physical dependency. They define independence as the ability to control whatever help is required to achieve chosen goals (J. Morris, 1997; 2001; Shakespeare, 2000b). 
However, other writers point out that dependence itself is a multifaceted concept, so it is not enough to reject the concept of dependence in favour of independence as autonomy (Fine \& Glendinning, 2005). For instance, there is a sense that dependence and interdependence are basic aspects of the human condition and a feature of all relationships (Shakespeare, 2000b; Fine \& Glendinning, 2005). Although this view does not deny that care could sometimes lead to social dependency, it acknowledges that dependency is a basic condition that makes all interdependency possible.

There are interesting dimensions of dependence, independence and interdependence throughout the papers that further complicate and blur the distinctions between these concepts. For instance, an interesting thought is whether the couples used their dependence on each other to be independent of care from others and to maintain autonomy throughout old age. Some examples in Papers I, II and III would suggest this. As discussed in Paper IV, the couples actually did regard themselves as being more independent and ready for change than other older people with late-onset disabilities. They also tended to see personal qualities such as never giving up as attributes of the relationship itself (Paper II). The idea of creating autonomy and independence through mutual caring and as a couple is an interesting one. From a post-modern perspective where the self is always embedded in a context, this interdependence may be understood as a kind of mutual responsibility (Reindal, 1999)-one that promotes autonomy for both partners. It is worth noting that the discourse of empowerment through care already exists to some extent, in the context of personal assistance. In personal relationships such as couplehood, it is feelings of friendship, affection, intimacy and love that could be the main reasons for desiring the autonomy and integrity of one's partner. Sometimes this may take expression in giving physical or emotional help, but at other times, this may mean balancing the desire to assist with respect for the partner's independence.

\section{The diversity of ageing experiences}

People do not have identical experiences of ageing. Despite this, interdisciplinary research that combines age and disability is still scarce (Sandvin, 2008; Spindel et al., 2012). The second main contribution of this thesis is thus an empirical one. It is achieved by describing the experiences of a group of older people that are only now beginning to be described in gerontological research. The study also contributes to showing the diversity of older people, in that the participants were neither the usual spousal carers, nor the usual successful agers. These empirical contributions could challenge ageist and disablist notions about growing old with long-term or lifelong disabilities, by allowing us to look at the categories "old age" and "disability" as other than merely negative constructions. Consequently, the study can also contribute to informing the alternative middle position between the binary discourses of old age that either frames ageing as 
inevitable decline or encourages responsibility for successful ageing through the denial of the failing body.

\section{From negative categories to positive resources}

The categories "old age" and "disability" are somewhat similar social constructions because they are often constructed as negative categories (Priestly, 2003). Both are often linked to loss of health and function, loss of independence and loss of engagement in social life (Priestly, 2003; Sandvin, 2008). Older people with long-term or lifelong disabilities, such as those in this study, would thus seem to occupy a situation of "double jeopardy" (see e.g. Walker \& Walker, 1998; Thorsen, 2003), as they live with the multiple negative effects of high age and a body marked with impairments. On the one hand, it is of course important to describe the issues that affect this group. As suggested in Chapter 1, people "ageing with disability" may have different experiences and also face different challenges to people "ageing into disability" (Yorkston et al., 2010). On the other hand, without looking at the experiences of older people with disabilities themselves, there may also be a risk of reproducing ageist and disablist assumptions about what old age and disability mean for individuals.

The results of this study show that the multiple negative effects of ageing with disability are only part of the picture. Neither "old age" nor "disability" are categorically negative constructions, and they were referred to by the interviewed couples as positive resources when talking about their experiences. For example, being an older people with disabilities was expressed not only as a challenge but also as a strength.

So on the one hand, the papers show that impairments due to age or disability have practical consequences in actualizing, planning and worrying about care (Paper I). The moral obligation to care could also be experienced as a constraint and an imperative that one cannot live up to all the time (Paper III). On the other hand, an interesting contrast to this is that the embodied experiences of disability were regarded as an actual resource for caring (Paper III). It is further suggested that the shared experience of disability might also have had an impact on the couples' abilities to see themselves as growing old together in an advantaged way (Paper IV).

These results show that the experiences of ageing with a disability do not appear only to be negative. What can be concluded from the results of this thesis is that the shared experience of long-term disability in old age can be a common concern in the family but also a common advantage.

\section{From binary discourses to affirmative old age}

Sandberg (2013) observes that discourses on ageing are often narrow and binary: they are either about decline or successful ageing. She suggests that there is a 
need to theorize old age in other ways and proposes the development of "affirmative old age" as an alternative conceptualization. Affirmative old age, according to Sandberg, should not be understood as similar to successful or positive ageing. Neither should it be seen as a typology whereby some people can be categorized as embodying affirmative old age, and others not. Rather, what it seeks to affirm is the materiality and facticity of the ageing body. This is opposed to the usual ways of seeing ageing as a negation in reference to a youthful ideal.

Affirmative old age, according to Sandberg, would reflect the complex and contradictory narratives on ageing in terms of difference. However, as it is also a reaction to a discourse that gives little positive content to old age, my understanding is that affirmative old age could also contribute to filling old age, as a category, with joyful and positive meanings. Sandberg also seems to lean towards this positive interpretation when she writes about the possibility of applying this concept to experiences of pain and vulnerability in old age (2013, p. 34). This present study, with its focus on older people with long-term and lifelong disabilities, could indeed contribute empirically to showing the diversity of ageing experiences. However, it also informs the discussion on affirmative old age. A long life with physical disabilities can have unique and positive meanings, even as one acknowledges and affirms the vulnerabilities that such a life might entail. Paper IV particularly contributes to the above discussion through demonstrating how the couples seemed to be able to participate in both discourses of having a body with disabilities and successfully ageing. The binary discourses of old age, in contrast, would exclude this group from a successful ageing discourse, since established ways of understanding successful ageing takes high physical function as a prerequisite (Scheidt, Humpherys \& Yorgason, 1999; Strawbridge et al., 2002). Nonetheless, the thesis as a whole also contributes to a more affirmative picture of older people with disabilities. It does this through describing older people with disabilities as agents in a care relationship, when they usually tend to be described and framed as passive and vulnerable receivers of help. The aspect of agency was emphasized for example, by underlining the participants' own choice to care, even though they did not fit the usual idea of a carer. Agency through caring could also be seen in the ways mutual caring was used to maintain privacy and integrity, rather than in relation to loss and inability.

\section{Final reflections}

\section{Caring with disabilities - Extraordinary?}

An important consideration should be mentioned at this point, regarding whether this study problematizes or rather reproduces the idea that caring for family members with disabilities is somehow different-more problematic or 
more "special" - than family life in general. Shakespeare (2000b) writes about the way that all families are interdependent. Yet the way caring literature is framed, he criticizes, suggests that caring for family members with disabilities is problematic or pathological, while other family relationships are harmless and benign. A similar line of thought is behind the idea that ageing with disabilities is more challenging than "normal ageing". The issue here is whether research tends to ascribe special qualities to the ageing and caring experience, only because those involved have disabilities. For instance, examples mentioned in the papers of couples helping each other with household chores such as cooking or doing groceries beg the question of whether these activities should really be considered as care work, when they would perhaps be classified as normal chores in other reciprocal relationships. The answer is that, naturally, the interviewed couples are just like any other couple in many respects. In Paper III, continuing caregiving for a spouse despite disability was explained as having the dimension of a moral obligation, but indeed, there is no reason to believe that aspects of love or moral obligation should be any different for the interviewed couples than for other families.

My interpretation of these actions as full-fledged activities of care should instead be viewed from a broader perspective where people with disabilities have often been framed in positions of dependence and passivity with regard to care. It is provocative to think, for example, that some of the tasks carried out by the informants may have been classified as care work had the same tasks been done by a paid professional or a younger (presumably also non-disabled) person identified as a family carer. Yet we should not forget that the participants sometimes provided care tasks with physical difficulty, as an expression of their choice to provide care themselves. In many cases, the management of care also required much use of time for the individuals. Furthermore, some ordinary activities described in the papers, such as having a picnic, watching a movie, listening to music together or travelling, also turned out to be significant in replacing or compensating for the meaningful individual activities that the participants had been obliged to give up due to their disabilities. That ordinary activities could have implications for participation and quality of life despite disabilities is also presented in Papers III and IV.

In the 1980s, when feminist researchers wanted to legitimate and acknowledge "women's work" in the household as care, this was also in the background of a discourse that diminished this work as "natural" family duties and a labour of love (Finch \& Groves, 1983). Some argue that the timedemanding invisible work being done by many women with regard to the planning and evaluation of care is still not given proper attention or acknowledgement (Bowlby, 2012). With regard to this present study, one could likewise ask how else one could make the informal caring of people with disabilities visible if we do not acknowledge some "ordinary" help tasks as care 
work. A further implication of considering the embodiedness of care work is that not all care tasks are bound to be alike. Perhaps this fact calls for a broadening of what is usually meant by care, rather than ascribing it a meaning of being something only certain people with high physical functioning can perform. Not doing so would have the inverted risk of regarding people with disabilities always only as receivers of help because their work is reduced to "natural parts of the relationship" or "mere" chores.

In this respect, Sevenhuijsen's (1998) work on the ethics of care is a useful way to see care. She writes that "practically all human behaviour carries aspects or dimensions of care, even though there is certainly not always an official vocabulary for expressing this" (p. 23). She also suggests that a starting point for understanding care practices would be to describe care as a social practice, "provided the practice of care is not exclusively sought in that which is generally thought of as care: the relations between 'caring' and 'dependent' people in situations of child-rearing, sickness and social need" (p. 23). This is what I have tried to do in this study by showing different types of care and carers that have until now been neglected. A conclusion here is that while relationships of interdependence might be the same for the interviewed couples as for others, there also needs to be a way of acknowledging the care work of older people with disabilities in order to break free from their conceptual "othering".

\section{Mutual care - Idealized?}

A related question that should be raised at the end of this thesis is whether the study idealizes or romanticizes mutual caring in intimate relationships. Even though my own participants tended to see caring as a "natural" or "automatic" part of the relationship, it should be remembered that "the ability to cope is not magically 'bestowed with the wedding ring'" (Parker, 1993, p. 124). As Parker notes, it cannot be assumed that the marital bond makes caring for a partner any easier. Even if emotional closeness - the raison d'être of the intimate partnershipis the reason that help is given, caring still imposes physical and emotional pressures on the caring partner and can cause constraints in the marital relationship (Parker, 1993). These facts should be acknowledged

I have of course been aware of this issue from the start, as well as the need to give a balanced picture of caring among older couples with disabilities. At the very least, I needed to take this question seriously because of the dyadic study design chosen. Therefore, throughout this thesis, I tried to balance the positive and less positive aspects of ageing and caring with disabilities. In Paper I, this was done through pointing to the many practical concerns which the couples had. I underlined that care work was not natural or easy, despite the everydayness of care in the couples' lives. In Paper II, I outlined the methodological implications as well as the limitations of conjoint interviewing for discovering aspects of conflict and disagreement. In Paper III, I aimed to describe the challenges of 
caring in more detail through the category Mutual care as imperative. This category revealed aspects of care not necessarily related to choice or freedom. On the one hand, care was expressed as just a "part of their lives" - something that needed to be done. On the other hand, caring was also a moral obligation that sometimes weighed heavily on the participants. Lastly, in Paper IV, I also showed that the couples' interpretations of themselves as ageing in a privileged way did not mean the subsequent denial of the difficulties of living together with disabilities.

Although it has not been the intention of this thesis to reify care as something that is only positive, it can be argued that this thesis also leans towards a more positive description of the spouses' mutual caregiving. This is especially so when one contrasts the discussion with previous literature on care burden and stress, which is quite common in spousal care literature. Indeed, as raised in Paper IV, it may just as well be possible to interpret the couples' situations as causing a situation of multiple jeopardy, rather than an affirmative picture of ageing.

Part of this leaning towards a positive interpretation, as discussed in Paper II, has to do with the conjoint interview method. As in other studies where informants themselves choose to be included, there might be a participant bias for couples with smooth-going relationships. Couples interviewed together may also be more inclined to give positive stories about their common experiences. On the one hand, this may cast a shadow on other aspects of care such as hard work and lack of choice. On the other hand, the dyadic perspective also means that the reciprocity between the couple-shaped by norms, expectations as well as feelings of commitment and love as outlined in Paper III-was an inseparable context in which caring was described and analysed. In turn, the concepts constructed in this thesis also have this relational character, with a leaning to positive dimensions of care.

Nevertheless, the results of this study can be seen as presenting an alternative perspective. As other researchers criticize, studies that have focused only on the individual impacts of caregiving have neglected the dynamics of the family and the positive impacts of caring (Walker \& Luszcz, 2009; Borgermans, Nolan \& Philip, 2001). However, as other studies demonstrate, caregiving burden and caregiver well-being are two sides of the same coin in understanding the dynamics of family caregiving (Chappell \& Reid, 2002). Among other research that has primarily focused on individual burdens of caring, the insights from this thesis help demonstrate that caring can also have shared advantages and shared concerns.

Ultimately, challenging the burden perspective involves more than just attributing positive values to caregiving. It has to do with representing care receivers as something other than a care burden. It also has to do with understanding the concept of care and its actors in new ways that recognizes care's situatedness in the complexity of relationships. This also has implications 
for practice. In a demographic outlook where people are living longer, older people and especially older people with disabilities might represent the bulk of informal caregivers in the future. Nurses and social workers involved with families can play an important role in identifying this undervalued group of older carers. Yet this group should be recognized as providers of care, without describing their caregiving only in terms of the additional physical and psychological burden for them. As McKee et al. (2003) point out, "directing supportive efforts only towards the reduction of burden may actually serve to make a caregiving relationship more problematic, while ignoring opportunities to enhance the satisfactions gained from the relationship" (p. 39). It was thus suggested in Paper III that health care professionals need to be sensitive to the dynamics of relationships and carefully explore family members' preferences for how formal support can best be provided in ways that honour and sustain the integrity of the relationship. A view that recognizes the positive aspects of giving and receiving informal care among those who might otherwise be constructed as society's weakest members makes it possible to see them as agents, rather than just objects or victims of care.

\section{Conclusion}

In gerontology and care research, care is often studied in ways in which older people and people with disabilities are portrayed as dependent on the care of younger or non-disabled people. This thesis, in contrast, studied care between people that were both old and had long-term or lifelong physical disabilities. I explored how care is actualized and experienced by older couples with disabilities, and investigated the implications of this caring in their lives.

In conclusion, this thesis offers two main contributions: it describes care as a dynamic activity and shows the diversity of ageing experiences. First, the study shows care as a dynamic activity that involves different roles and activities over time. Boundaries between carer/care receiver, caring/servicing and dependence/independence blur and intermesh in the dynamics of relationships. Second, in describing participants that were neither the usual spousal carers nor the usual successful agers, this study also shows the diversity of ageing experiences. It presents how the couples could regard old age and disability as resources, opening up ways to understand affirmative old age with disabilities.

My hope is that this thesis can contribute to the still growing literature on ageing with a disability, but also to the interdisciplinary discussions about ageing, disability, and informal caring. Exploring other actors and meanings of care that are often neglected certainly has an empirical value, but it also has a value in deconstructing ageist and disablist notions that may underlie care research. It also has a practical value in allowing researchers and practitioners to acknowledge the care work provided by people with disabilities, which may otherwise be hidden. 



\section{Summary in Swedish Åldrande och omsorg hos par med funktionshinder}

Äldre och personer med funktionshinder ses ofta som mottagare av olika typer av omsorg från andra. I kontrast till detta är fokus i denna avhandling det omsorgsarbete som utförs av äldre personer med långvariga eller livslånga funktionshinder.

Syftena med avhandlingen är dels att studera hur omsorg kan aktualiseras och förstås hos äldre par där båda har levt långa liv med fysiska funktionshinder, dels att undersöka vad den ömsesidiga omsorgen kan ha för betydelse i dessa pars liv. Avhandlingen är en interdisciplinär studie i gränslandet mellan gerontologi, omsorgsforskning och funktionshinderforskning. Varken anhörigomsorg för vuxna med funktionshinder eller åldrande med funktionshinder har belysts speciellt mycket $\mathrm{i}$ dessa tre fält. Ambitionen med avhandlingen är således att kunna bidra teoretiskt till omsorgsbegreppet. Den tillför också ett empiriskt bidrag i forskningen genom att beskriva en grupp äldre som sällan ses i gerontologin.

De övergripande frågorna i denna avhandling är följande: Hur kan omsorgen se ut hos par som åldras tillsammans med långvariga eller livslånga funktionshinder? Vad kan denna omsorg ha för implikationer, när paren åldras med sina funktionshinder?

För att undersöka dessa frågor valde jag att göra kvalitativa intervjuer med par där båda parter har haft fysiska funktionshinder under lång tid. Nio par mellan 60 och 84 års ålder, där många har haft fysiska funktionshinder i 20 år eller mer, var med i studien. Merparten fick jag kontakt med genom funktionshinderföreningar. Personerna var dock olika vad gäller typ av funktionshinder, hur lång tid de har haft funktionshinder och hur mycket hjälp de behövde i vardagen. Det kunde röra sig om exempelvis CP-skada, polioskada, MS, synnedsättning, medfödda skador eller kroniska sjukdomar som man har haft sedan länge. Efter etiska överväganden valde jag att intervjua dem i par. Intervjuer där två personer ställer upp i en och samma intervjusituation brukar kallas parintervjuer (conjoint interviews). Första intervjuomgången gjordes år 2010. Fyra av dessa nio par gav också senare sitt medgivande till en uppföljningsintervju år 2012.

Analysen gjorde jag med hjälp av analytiska verktyg inom grundad teori. 
Kvalitativ analys enligt grundad teori är inriktad på att belysa, förstå eller förklara ett fenomen genom att bygga trovärdiga tolkningar så nära de empiriska data som möjligt, för att sedan kunna belysa, förstå eller förklara fenomenet i frågan. Kodning (coding) betyder att jag har noggrant läst genom intervjuerna och tolkat handlingar och uttryck i dessa genom att sätta rubriker eller ord som jag tycker bäst beskriver dem. I takt med att man kodar fler intervjuer blir kodningsarbetet mer fokuserat på de teman som framträder. Detta kallas för fokuserad kodning (focused coding). Grundad teori bygger också på att hela tiden jämföra olika kodgrupper och dataavsnitt mot varandra (constant comparison). Kodgrupperna tillämpas och testas i olika intervjudelar för att kunna se kontraster, mönster eller nyanser i koncepten. Ambitionen med att utgå från grundad teori är att bygga koncept och kategori som ligger nära data. Trots det är all kvalitativ analys oundvikligt konstruerad utifrån forskarens egna förförståelse och forskningsbakgrund.

En teoretisk tolkningsram som påverkade mig i min analys är livsloppsperspektivet. Detta är ett teoretiskt perspektiv som handlar om att se åldrandet som en livslång process och förstå det genom att se på hela livets dynamik. I praktiska termer betyder livsloppsperspektivet att forskaren tar hänsyn till olika tidsrelaterade aspekter i sin tolkning. . Till exempel har den långa tiden med funktionshinder, tiden paren levt tillsammans och funktionshinderpolitiken i historisk tid, betydelse för parens erfarenheter av och förväntningar på att åldras och ge varandra omsorg.

Avhandlingen är en sammanläggningsavhandling som består av fyra texter, Studie I, II, III och IV. Alla belyser forskningsfrågorna på olika sätt.

\section{Studie I}

\section{Åldrande och omsorg hos par med funktionshinder}

Studie I diskuterar frågan, om man kan vara omsorgsgivare när man själv har hjälpbehov. Hur ser omsorgen ut och hur förändras förutsättningarna för att kunna ge hjälp, när man själv åldras med funktionshinder? Resultaten visar att paren utbytte mycket hjälp och stöd, trots egna funktionshinder. Detta kunde vara fysiskt omsorgsarbete, såsom hjälp med att äta, duscha eller gå på toaletten. Hjälpen kunde också vara osynlig, såsom moraliskt stöd, stöd med att planera assistans eller att ha koll på sin partners hälsa. Många av dessa omsorgsinsatser "gömde sig" bakom parens vardagsmönster (the everydayness of care), så att de inte betraktades som omsorgsaktivitet. Snarare ansågs den ömsesidiga omsorgen som ett praktiskt sätt att bara få vardagen med funktionshinder att fungera (making things work). Dock kunde problem uppstå om någon av parterna plötsligt inte kunde ge hjälp. Paren oroade sig för en framtid där de skulle behöva mer omsorg, men kanske inte längre kan ge så mycket hjälp. 
Resultaten från denna studie lyfter fram viktiga dimensioner av omsorg. För det första har omsorg en tidsdimension. Omsorgen är alltså inte begränsad till aktiviteter i nuet utan sträcker sig i tid, genom att paren hela tiden planerar, evaluerar och bedömer sin omsorgssituation. För det andra har också omsorg en fysisk dimension, eftersom den utförs med kroppen. Funktionsnedsättning, antingen på grund av ålder eller sjukdom, innebär skiftande hjälpbehov men också begränsade möjligheter till att fortsätta ge hjälp.

\section{Studie II}

\section{Att göra parintervjuer med par som har levt en lång tid med funktionshinder - Konsekvenser av och insikter om metoden}

Studie II handlar om metodologiska implikationer av att intervjua i par, där temat för intervjun är ömsesidig omsorg. Vad är det som kännetecknar data från parintervju? Hur har data format analysen? I denna studie använder jag mig av konkreta exempel från intervjuerna för att visa de unika egenskaperna hos intervjudatan. I studien diskuteras också begränsningarna och möjligheterna som metoden ger. Parintervjuer producerar en annan typ av data än vad som är möjligt från intervjuer med enskilda. För det första betonade paren-både i sina berättelser och i sitt sätt att berätta-ett "vi"-begrepp (we-talk och we-ness). Att vara "vi" visade sig inte enbart som språklig effekt av intervjuutförandet. Det levda livet ihop och delad erfarenhet av funktionshinder sågs också som en resurs för att kunna ge hjälp. För det andra gav också parintervjun möjlighet till interaktion (performative data). Det kunde handla om att bekräfta, diskutera eller inte hålla med. Men paren utbytte också hjälp från varandra under själva intervjun.

Som alla andra metoder har parintervjuer sina begränsningar som gör att de kan vara mindre lämpliga för forskning om andra teman. Men metoden har också fördelar; den kan belysa relationella fenomen på ett annat sätt än individuella intervjuer gör och resultera i ny kunskap. Till exempel har partintervjun gjort det möjligt att diskutera informell omsorg utan att i förhand tillskriva någon av partnerna fasta roller som "omsorgsgivare" och "omsorgstagare".

\section{Studie III}

\section{Frihet och nödvändighet: Ömsesidig omsorg hos äldre par med fysiska funktionshinder}

Studie III fokuserar på den ömsesidiga omsorgen och hur denna kan förstås när paren samtidigt är berättigade till formellt stöd och hjälp. Paren hade t.ex. hemtjänst eller personlig assistans men hjälpte varandra på en mängd olika sätt. 
Varför ges denna hjälp, trots svårigheterna att utföra den och trots att annat stöd och hjälp finns? Hur formar relationen omsorgsombytet? Analysarbetet ledde till två övergripande kategorier för hur omsorgen kan förstås.

Den ena, Ömsesidig omsorg som frihet (Mutual care as freedom), visar att omsorgen inte enbart var för det instrumentella målet att kunna utföra uppgifter. Paren utbytte också hjälp för att bland annat kunna vara fria från den formella omsorgen, eller för att bara kunna vara "sig själva". Men parförhållandet innebär också normer och förväntningar att man "bör" hjälpa varandra. Man kan också vara "tvingad" av situationen att ge hjälp. Dessa dimensioner diskuteras i den andra kategorin, Ömsesidig omsorg som nödvändighet (Mutual care as imperative). Omsorgen från partnern upplevdes som mer pålitlig och personlig. Å andra sidan kan förväntningarna också vara betungande, eller ett "jobb" som kan vara svårt att leva upp till när man själv har fysiska svårigheter.

Resultaten visar på ett mer komplext förhållande mellan formell och informell hjälp än som substitut eller komplement till varandra. Resultaten tyder också på att vårdpersonalen behöver vara lyhörd och noga undersöka parets preferenser för hur stöd och hjälp utformas, på ett sätt som upprätthåller integriteten i parförhållandet.

\section{Studie IV}

\section{Äldre par med långvariga funktionshinder: dubbelutsatthet eller gott åldrande?}

Idén för Studie IV kom från ett oväntat tema som jag anade redan i första intervjuomgången men som tydligt dök upp i intervjuerna år 2012. Detta tema handlade om hur de intervjuade paren ansåg sig ha ett bättre åldrande jämfört med andra grupper, trots egna berättelser om fysiska försämringar och ett mer begränsat liv. I vilka avseenden betraktade de sitt åldrande som gynnsamt, trots att de båda åldrades med funktionshinder? Hur kan man förstå ett aktivt åldrande med funktionsnedsättning?

Studien är utformad som en kritik av Rowe och Kahns etablerade begrepp successful ageing (framgångsrikt åldrande eller det goda åldrandet). Det goda åldrandet, enligt Rowe and Kahn, kännetecknas av relativt god hälsa och funktionalitet. I studien diskuteras däremot både subjektiva och objektiva aspekter på hur man skulle kunna se parens situation som framgångsrikt åldrande, trots att båda åldras med långvariga eller livslånga funktionshinder. Miljöanpassningar, tekniska hjälpmedel och stödinsatser är förstås viktiga för att kunna hålla relativt hög aktivitetsnivå enligt nya förutsättningar. Men det framstod också att paren kunde beskriva sig själva som priviligierade eller att ha ett gynnsamt åldrande, med hänvisning till precis de egenskaper som många kan tycka är ofördelaktiga. Paren ansåg att den långa tiden med funktionshinder och att vara två personer med funktionshinder var skäl till att de åldras "bättre än 
andra". Detta tyder på att det alltid är problematiskt med bestämda kriterier för vad ett framgångsrikt åldrande "verkligen är".

De fyra studierna bidrar på olika sätt till att belysa avhandlingens övergripande forskningsfrågor. Jag kunde visa att äldre par med funktionshinder ger och tar emot olika typer av hjälp och omsorg från varandra, utan att det nödvändigtvis betraktades som omsorgsarbete. Hjälp kunde vara allting ifrån moraliskt stöd eller hjälp med hushållssysslor, till kommunikativ hjälp och uppgifter som man traditionellt förknippar med äldreomsorg. Dock bygger denna ömsesidiga omsorg på egen förmåga att ge hjälp, vilket kan svikta när man själv har funktionshinder. Detta kan orsaka oro för paren, när de tänker på sin framtid. Ibland kan omsorgsansvaret också vara betungande, när man själv upplever dålig hälsa. ̊̊ andra sidan kunde den delade erfarenheten av funktionshinder anses som en omsorgsresurs. Att åldras tillsammans med funktionshinder och att ge omsorg trots egna funktionshinder är alltså inte enbart negativt laddat utan kan förknippas med hög livskvalitet, frihetskänsla och autonomi.

De viktigaste resultaten från denna avhandling är, för det första, att visa på hur omsorg är en dynamisk aktivitet som innebär olika roller och uttryck under livets gång. Omsorgsbegreppet brukar förstås med hjälp av olika dikotomier, såsom omsorgsgivare/omsorgstagare, omsorg/service och beroende/oberoende. Exempel i denna avhandling visar däremot att gränserna mellan dessa dikotomier inte är så självklara.

För det andra visar avhandlingen på åldrandets mångfald. Åldersdiskurserna brukar röra sig om två extrema positioner, där den ena bedömer åldrandet som förlust och förfall och den andra uppmanar till framgångskrikt åldrande genom bibehållandet av ungdomliga och vitala egenskaper trots åldern. Att äldre personer kan uppleva och erkänna fysiska svårigheter och samtidigt känna igen sig i diskurser om det positiva åldrandet, är något som denna avhandling visar.

Att undersöka andra aktörer och andra former av omsorg har förvisso ett empiriskt värde men kan också bidra till att utmana negativa föreställningar om äldre och personer med funktionshinder som enbart beroende och passiva mottagare av omsorgsinsatser. Avhandlingen har också praktiska implikationer i verksamheter som rör äldre och personer med funktionshinder. Den uppmanar till att synliggöra och uppmärksamma det ofta dolda omsorgsarbete som utförs av äldre och funktionshindrade personer. 



\section{References}

Agree, E.M. (2014). The potential for technology to enhance independence for those aging with a disability. Disability and Health Journal, 7(1), S33-S39.

Ahlström, G. \& Wadensten, B. (2011). Family members' experiences of personal assistance given to a relative with disabilities. Health and Social Care in the Community, 19(6), 645-652.

Ahn, T., \& Kim, K. (2007). Mutual caring of elderly Korean couples. Journal of Transcultural Nursing, 18(1), 28-34.

Allan, G. (1980). A note on interviewing spouses together. Journal of Marriage and the Family, 42(1), 205-210.

Anttonen, A. (2002). Universalism and social policy: A Nordic-feminist revaluation. NORA-Nordic Journal of Feminist and Gender Research, 10(2), 7180 .

Arskey, H. (1996). Collecting data through joint interviews. Social Research Update, 15, 1-8.

Australian Bureau of Statistics. (2009). Disability, ageing and carers, Australia: Summary of findings. Canberra: ABS.

Backman, K. \& Kyngäs, H.A. (1999). Challenges of the grounded theory approach to a novice researcher. Nursing and Health Sciences, 1(3),147-153.

Barron, K., Michailakis, D., \& Söder, M. (2000). Funktionshindrade och den offentliga hjälpapparanten [People with disabilities and the system of formal support]. In M. Szebehely (Ed.), Välfärd, vård och omsorg [Welfare and care] (Swedish Government Official Report SOU 2000:38, Research anthology) (pp. 137-170). Stockholm: Fritzes.

Beauchamp, T.L. \& Childress, J.F. (2001). Principles of biomedical ethics (5 $5^{\text {th }}$ ed.). Oxford: Oxford University Press.

Beckett, C. (2007). Women, disability, care: Good neighbours or uneasy bedfellows? Critical Social Policy, 27(3), 360-380.

Bennett, L.A. \& McAvity, K.J. (1994). Family research: A case for interviewing couples. In G. Handel and G. Whitchurch (Eds.), The Psychosocial Interior of the Family (4 $4^{\text {th }}$ ed.) (pp. 87-107). New York: Walter de Gruyter.

Bettio, F. \& Plantenga, J. (2004). Comparing care regimes in Europe. Feminist Economics, 10(1), 85-113. 
Bigby, C. (2004). Ageing with a lifelong disability. A guide to practice, program and policy issues for human services professionals. London: Jessica Kingsley.

Biggs, S. \& Daatland, S.O. (2004). Ageing and diversity: A critical introduction. In S.O. Daatland \& S. Biggs (Eds.), Ageing and diversity. Multiple pathways and cultural migrations (pp. 1-12). Bristol: Policy Press.

Blieszner, R. (2006). A lifetime of caring: Dimensions and dynamics in late-life close relationships. Personal Relationships, 13(1), 1-18.

Boeije, H. (2002). A purposeful approach to the constant comparative method in the analysis of qualitative interviews. Quality and Quantity, 36(4), 391-409.

Borgermans, L., Nolan, M. \& Philip, I. (2001). Europe. In I. Philip (Ed.), Family care of older people in Europe (pp. 1-26). Amsterdam: IOS Press.

Bowlby, S. (2012). Recognising the time-space dimensions of care: Caringscapes and carescapes. Environment and Planning A, 44(9), 2101-2118.

Brown, R. (1996). Partnership and marriage in Down syndrome. Down Syndrome Research and Practice, 4(3), 96-99.

Bryant, A. \& Charmaz, K. (2007a). Introduction. Grounded theory research: Methods and practices. In A. Bryant \& K. Charmaz (Eds.), The SAGE handbook of grounded theory (pp. 1-28). London: Sage.

Bryant, A. \& Charmaz, K. (2007b). Grounded theory in historical perspective: An epistemlogical account. In A. Bryant \& K. Charmaz (Eds.), The SAGE handbook of grounded theory (pp. 32-57). London: Sage.

Bytheway, B. (2011). Unmasking age. The significance of age for social research. Bristol: Policy Press.

Chappell, N.L. \& Reid, R.C. (2002). Burden and well-being among caregivers: Examining the distinction. The Gerontologist, 42(6), 772-780.

Charmaz, K. (2006). Constructing grounded theory. A practical guide through qualitative analysis. London: Sage.

Clarke, A. (2005). Situational analysis. Grounded theory after the postmodern turn. Thousand Oaks: Sage.

Clevnert, U. \& Johansson, L. (2007). Personal assistance in Sweden. Journal of Aging and Social Policy, 19(3), 65-80.

Corbin, J. \& Strauss, A. (2008). Basics of qualitative research: Techniques and procedures for developing grounded theory ( $3^{\text {rd }}$ ed.). Thousand Oaks: Sage.

Corden, A. \& Hirst, M. (2011). Partner care at the end-of-life: Identity, language and characteristics. Ageing and Society, 31(2), 217-242.

Daatland, S.O. \& Herlofsson, K. (2001). Service systems and family careSubstitution or complementarity? In S.O. Daatland \& K. Herlofsson (Eds.), Ageing, intergenerational relations, care systems and quality of life: An introduction to the OASIS project (Norwegian Social Research Report 14/10) (pp. 53-62). Oslo: NOVA.

Daly, M. \& Lewis, J. (2000). The concept of care and the analysis of contemporary welfare states. British Journal of Sociology, 51(2), 281-298. 
Davidson, K. (2011). Sociological perspectives on ageing. In I. Stuart-Hamilton (Ed.), An introduction to gerontology (pp. 226-250). Cambridge: Cambridge University Press.

Davis, L.J. (2006). Constructing normalcy: The bell curve, the novel, and the invention of the disabled body in the nineteeth century. In L.J. Davis (Ed.), The disability studies reader. New York: Routledge.

Davis, L.L., Gilliss, C.L., Deshefy-Longi, T., Chestnutt, D.H. \& Molloy, M. (2011). The nature and scope of stressful spousal caregiving relationships. Journal of Family Nursing, 17(2), 224-240.

Doran, T., Drever, F. \& Whitehead, M. (2003). Health of young and elderly informal carers: Analysis of UK census data. British Medical Journal, 327(7428), 1388.

Edebalk, P.G. (2000). Emergence of a welfare state-Social insurance in Sweden in the 1910s. International Social Policy, 29(4), 537-551.

Eisikovits, Z. \& Koren, C. (2010). Approaches to and outcomes of dyadic interview analysis. Qualitative Health Research, 20(12), 1642-1655.

Eliasson, R. (Ed.) (1996). Omsorgens skiftningar. Begreppet, vardagen, politiken, forskningen [Care's nuances. Concept, everyday life, politics and research]. Lund: Studentlitteratur.

Finch, J. \& Groves, D. (Eds.) (1983). A labour of love: Women, work and caring. London: Routledge and Kegan Paul.

Fine, M. \& Glendinning, C. (2005). Dependence, independence or interdependence? Revisiting the concepts of 'care' and 'dependency'. Ageing and Society, 25(4), 601-621.

Forbat, L. \& Henderson, J. (2003). "Stuck in the middle with you": The ethics and process of qualitative research with two people in an intimate relationship. Qualitative Health Research, 13(10), 1453-1462.

George, L.K. (2013). Age structures, aging and the life course. In J.M. Wilmoth \& K.F. Ferraro (Eds.), Gerontology: Perspectives and issues (4th ed.) (pp. 149-172). New York: Springer.

Giele, J.Z. \& Elder, G.H. (1998). Life course research. Development of a field. In J.Z. Giele \& G.H. Elder (Eds.), Methods of life course research (pp. 5-27). Thousand Oaks: Sage.

Gilson, S.F. \& Netting, F.E. (1997). When people with pre-existing disabilities age in place: Implications for social work practice. Health and Social Work, 22(4), 290-298.

Glaser, B. \& Strauss, A. (1967). The discovery of grounded theory: Strategies for qualitative research. Chicago: Aldine.

Glendinning, C. \& Kemp, P.A. (Eds.) (2006). Cash and care. Policy challenges in the welfare state. Bristol: Policy Press.

Goodley, D. (2011). Disability studies. An interdisciplinary approach. London: Sage.

Graham, H. (1983). Caring: A labour of love. In J. Finch \& D. Groves (Eds.), A 
labour of love: women, work and caring (pp. 13-30). London: Routledge and Kegan Paul.

Grönvik, L. (2007). The fuzzy buzz word: Conceptualizations of disability in disability research classics. Sociology of Health and Illness, 29(5), 750-766.

Grönvik, L. (2009). Defining disability: Effects of disability concepts on research outcomes. International Journal of Social Research Methodology, 12(1), 1-18.

Gustavsson, A. (2004). Inledning [Introduction]. In A. Gustavsson (Ed.), Delaktighetens språk [The language of participation]. Lund: Studentlitteratur.

Higgs, P. \& Jones, I.R. (2009). Medical sociology and old age. Towards a sociology of health in later life. London: Routledge.

Holme, L. (2013). Disability, identity and ageing. In E. Jeppsson Grassman \& A. Whitaker (Eds.), Ageing with disability. A lifecourse perspective (pp. 35-53). Bristol: Policy Press.

Holstein, J. \& Gubrium, J.F. (1995). The active interview. Thousand Oaks: Sage.

Hughes, B., McKie, L., Hopkins, D. \& Watson, D. (2005). Love's labours lost? Feminism, the Disabled People's Movement and an ethic of care. Sociology, 39(2), 259-275.

Hunt, P. (1998). A critical condition. In T. Shakespeare (Ed.), The disability reader: Social science perspectives (pp. 7-19). London: Cassell.

Hydén, L-C. \& Bülow, P.H. (2003). Who's talking: Drawing conclusions from focus groups-Some methodological considerations. International Journal of Social Research Methodology, 6(4), 305-321.

James, N. (1992). Care = organization + physical labour + emotional labour. Sociology of Health and Illness, 14(4), 488-509.

Jegermalm, M. (2005). Carers in the welfare state. On informal care and support for carers in Sweden. Doctoral dissertation. Stockholm University, Department of Social Work.

Jegermalm, M. (2006). Informal care in Sweden: A typology of care and caregivers. International Journal of Social Welfare, 15(4), 332-343.

Jegermalm, M. \& Jeppsson Grassman, E. (2012). Helpful citizens and caring families: Patterns of informal help and caregiving in Sweden in a 17-year perspective. International Journal of Social Welfare, 21(4), 422-432.

Jeppsson Grassman, E. (2001). Medmänniska och anhörig. En studie av informella hjälpinsatser [Fellow man and relative. A study on informal help and care] (Sköndal Institute Writing Series 7). Stockholm: Sköndal Institute.

Jeppsson Grassman, E. (2003). Anhöriginsatser och medborgarengagemang [Family support and civil participation]. In E. Jeppsson Grassman (Ed.), Anhörigskapets uttrycksformer [Expressions of familiality] (pp. 23-53) Lund: Studentlitteratur.

Jeppsson Grassman, E. (2010). Welfare in Western Europe: Existing regimes and patterns of change. In A. Bäckström \& G. Davie (Eds.), Welfare and religion in 21st century Europe. Aldershot: Ashgate. 
Jeppsson Grassman, E. \& Whitaker, A. (2012). Omsorgens former och sammanhang-Utgångspunkter och perspektiv [The forms and contexts of care-Starting-points and perspectives]. In E. Jeppsson Grassman \& A Whitaker (Eds.), Aldrande och omsorgens gestaltningar [Ageing and forms of care] (pp. 13-29). Lund: Studentlitteratur.

Jeppsson Grassman, E. \& Whitaker, A. (2013). Ageing with disability: An introduction. In E. Jeppsson Grassman \& A. Whitaker (Eds.), Ageing with disability: A lifecourse perspective (pp. 1-15). Bristol: Policy Press.

Jeppsson Grassman, E., Whitaker, A. \& Taghizadeh Larsson, A. (2009). Family as failure? The role of informal help-givers to disabled people in Sweden. Scandinavian Journal of Disability Research, 11(1), 35-49.

Johansson, L., Long, H. \& Parker, M.G. (2011). Informal caregiving for elders in Sweden: An analysis of current policy developments. Journal of Aging and Social Policy, 23(4), 335-353.

Johansson, L. Sundström, G. \& Hassing, L. B. (2003). State provision down, offspring's up: The reverse substitution of old-age care in Sweden. Ageing and Society, 23(3), 269-280.

Jowsey, T., McRae, I., Gillespie, J., Banfield, M., \& Yen, L. (2013). Time to care? Health of informal carers and time spent on health related activities: An Australian survey. BMC Public Health, 13, 374-383.

Jönson, H. \& Taghizadeh Larsson, A. (2009). The exclusion of older people in disability activism and policies-A case of inadvertent ageism? Journal of Aging Studies, 23(1), 69-77.

Kelle, U. (2007). The development of categories: Different approaches in grounded theory. In A. Bryant \& K. Charmaz (Eds.), The SAGE handbook of grounded theory (pp. 191-213). London: Sage.

Kjellström, S., Ross, S.N. \& Frilund, B. (2010). Research ethics in dissertations: ethical issues and complexity of reasoning. Journal of Medical Ethics, 36(7), 425-430.

Klein, J.T. (2000). A conceptual vocabulary of interdisciplinary science. In P. Weingart \& N. Stehr (Eds.), Practising interdisciplinarity (pp. 3-24). Toronto: Univeristy of Toronto Press.

Knijin, T. \& Kremer, M. (1997). Gender and the caring dimension of welfare states: Toward an inclusive citizenship. Social Politics, 4(3), 328-361.

Krefting, L. (1991). Rigor in qualitative research: The assessment of trustworthiness. The American Journal of Occupational Therapy, 45(3), 214-222.

Kröger, T. (2009). Care research and disability studies: Nothing in common? Critical Social Policy, 29(3), 398-420.

Kvale, S. \& Brinkmann, S. (2009). Interviews. Learning the craft of qualitative research interviewing ( $2^{\text {nd }}$ ed.). Thousand Oaks: Sage.

LaPlante, M.P. (2014). Key goals and indicators for successful aging of adults with early-onset disability. Disability and Health Journal, 7(1), S44-S50. 
LaPlante, M.P., Carlson, D., Kaye, H.S. \& Bradsher, J.E. (1996). Families with disabilities in the United States (Disability Statistics Report 8). Washington, D.C.: National Institute on Disability and Rehabilitation Research.

Lavela, S.L., \& Ather, N. (2010). Psychological health in older adult spousal caregivers of older adults. Chronic Illness, 6(1), 67-80.

Leira, A. \& Saraceno, C. (2002). Care: Actors, relationships and contexts. In B. Hobson, J. Lewis \& B. Siim (Eds.), Contested concepts in gender and social politics (pp. 55-83). Cheltenham: Edward Elgar.

Leitner, S. (2003). Varieties of familialism: The caring function of the family in comparative perspective. European Societies, 5(4), 353-375.

Lincoln, Y.S. \& Guba, E.G. (1985). Naturalistic inquiry. London: Sage.

Lindqvist, R. (2012). Funktionshindrade i välfärdssamhället [People with disabilities in the welfare state] ( $3^{\text {rd }}$ ed.). Malmö: Gleerups.

Lloyd, M. (2001). The politics of disability and feminism: Discord or synthesis? Sociology, 35(3), 715-728.

Lyon, D. \& Glucksmann, M. (2008). Comparative configurations of care work across Europe. Sociology, 42(1), 101-118.

Mauthner, M. (2000). Snippets and silences: Ethics and reflexivity in narratives of sistering. International Journal of Social Research Methodology, 3(4), 287-306.

Maxwell, J.A. (1992). Understanding and validity in qualitative research. Harvard Educational Review, 62(3), 279-300.

McKee, K. J., Philp, I., Lamura, G., Prouskas, C., Öberg, B., Krevers, B., . . . Szczerbinska, K. (2003). The COPE index-A first stage assessment of negative impact, positive value and quality of support of caregiving in informal carers of older people. Aging \& Mental Health, 7(1), 39-52.

McKie, L., Gregory, S. \& Bowlby, S. (2002). Shadow times: The temporal and spatial frameworks and experiences of caring and working. Sociology, 36(4), 897-924.

Miller, S. \& Morgan, M. (1980). Marriage matters: For people with disabilities too. Sexuality and Disability, 3(3), 203-211.

Mills, J., Bonner, A. \& Francis, K. (2006). The development of constructivist grounded theory. International Journal of Qualitative Methods, 5(1), 1-10.

Minkler, M. \& Fadem, P. (2002). "Successful aging": A disability perspective. Journal of Disability Policy Studies, 12(4), 229-235.

Moll, L.R. \& Cott, C.A. (2013). The paradox of normalization through rehabilitation: Growing up and growing older with cerebral palsy. Disability and Rehabilitation, 35(15), 1276-1283.

Molyneaux, V., Butchard, S., Simpson, J. \& Murray, C. (2011). The coconstruction of couplehood in dementia. Dementia, 11(4), 483-502.

Monahan, D.J. \& Wolf, D.A. (2014). The continuum of disability over the lifespan: The convergence of aging with disability and aging into disability. Disability and Health Journal, 7(1), S1-S3. 
Morgan, D.L. (1996). Focus groups. Annual Review of Sociology, 22(1), 129-152.

Morris, J. (1997). Care or empowerment? A disability rights perspective. Social Policy and Administration, 31(1), 54-60.

Morris, J. (2001). Impairment and disability: Constructing an ethics of care that promotes human rights. Hypathia, 16(4), 1-16.

Morris, S.M. (2001). Joint and individual interviewing in the context of cancer. Qualitative Health Research, 11(4), 553-567.

Morse, J.M., Barrett, M., Mayan, M., Olson, K. \& Spiers, J. (2002). Verification strategies for establishing reliability and validity in qualitative research. International Journal of Qualitative Methods, 1(2), 13-22.

Naidoo, V., Putnam, M., \& Spindel, A. (2012). Key focal areas for bridging the fields of ageing and disability: Findings from the growing older with a disability conference. International Journal of Integrated Care, 12(8), 1-8.

Ngan, R. (2011). Social care and older people. In I. Stuart-Hamilton (Ed.), An introduction to gerontology (pp. 126-158). Cambridge: Cambridge University Press.

Nirje, B. (1969). The normalization principle and its human management implications. In R. Kugel \& W. Wolfensberger (Eds.), Changing patterns in residential services for the mentally retarded. Washington, D.C.: President's Committee on Mental Retardation.

Nolan, M., Grant, G. \& Keady, J. (1996). Understanding family care. Buckingham: Open University Press.

Nordberg, G. (2007). Formal and informal care in an urban and a rural elderly population. Who? When? What? Doctoral dissertation. Karolinska Institutet, Department of Neurobiology, Care Sciences and Society.

Nordenfelt, L. (1995). On the nature of health. An action-theoretic approach (2 $\left.{ }^{\text {nd }} \mathrm{ed}.\right)$. Dordrecht: Kluwer Academic Publishers.

Närvänen, A-L. (2004). Age, ageing and the life course. In B-M. Öberg, A-L. Närvänen, E. Näsman \& E. Olsson (Eds.), Changing worlds and the ageing subject. Dimensions in the study of ageing and later life (pp. 65-80). Aldershot: Ashgate.

Närvänen, A-L. \& Näsman, E. (2006). Challenging postmodern life courses? (Working Paper from NISAL 2006:2). Norrköping: NISAL.

O'Connell, B., Bailey, S. \& Walker, A. (2003). Promoting the health and wellbeing of older carers: A proactive strategy. Australian Health Review, 26(2), 78-86.

Office for National Statistics. (2009). UK life opportunities survey. Essex: UK Data Archive.

Oldman, C. (2002). Later life and the social model of disability: A comfortable partnership? Ageing and Society, 22(6), 791-806.

Oliver, M. (1990). The individual and social models of disability. Accessed 28 October 2013 from http://disability-studies.leeds.ac.uk/files/library/Oliver-in-socdis.pdf 
Parker, G. (1993). With this body. Caring and disability in marriage. Buckingham: Open University Press.

Pavolini, E. \& Ranchi, C. (2008). Restructuring the welfare state: Reforms in longterm care in Western European countries. Journal of European Social Policy, 18(3), 246-259.

Priestly, M. (2003). Disability: A life course approach. Cambridge: Polity.

Prilleltensky, O. (2004). My child is not my carer: Mothers with physical disabilities and the well-being of children. Disability and Society, 19(3), 209223.

Putnam, M. (2002). Linking aging theory of disability models: Increasing the potential to explore aging with physical impairment. The Gerontologist, 42(6), 799-806.

Putnam, M. (2007). Ageing and disability. Crossing network lines. New York: Springer.

Putnam, M. (2012). Can aging with a disability find a home in gerontological social work? Journal of Gerontological Social Work, 55(2), 91-94.

Racher, F.E., Kaufert, J.M. \& Havens, B. (2000). Conjoint research interviews with frail, elderly couples: Methodological implications. Journal of Family Nursing, 6(4), 367-379.

Ratzka, A. (2007). Independent Living for people with disabilities. Accessed 20 October 2013 from http://www.leeds.ac.uk/disabilitystudies/archiveuk/ratzka/2007\%2010\%20Barcelona\%20final.pdf

Rauch, D. (2007). Is there really a Scandinavian social service model? A comparison of childcare and elderycare in six European countries. Acta Sociologica, 50(3), 249-269.

Reindal, S.M. (1999). Interdependence, dependence, interdependence: Some reflections on the subject and personal autonomy. Disability and Society, 14(3), 353-367.

Reissman, C.K. (1993). Narrative analysis. Newbury Park, CA: Sage.

Rhoten, D. (2004). Interdisciplinary research: Trend or transition. Items-Social Science Research Council, 5(1-2), 6-11.

Rosenblum, L.P. (2000). Perceptions of the impact of visual impairment on the lives of adolescents. Journal of Visual Impairment and Blindness, 94(7), 434-445.

Rostgaard, T. \& Szebehely, M. (2012). Changing policies, changing patterns of care: Danish and Swedish home care at the crossroads. European Journal of Ageing, 9(2), 101-109.

Rowe, J.W. \& Kahn, R.L. (1997). Successful aging. The Gerontologist, 37(4), 433-440.

Salminen-Karlsson, M. (2002). Glaser mot Strauss-Två utvecklingar av grounded theory [Glaser vs. Strauss-Two evolutions of grounded theory]. Socialvetenskaplig tidskrift, 9(1), 49-62.

Sandberg, L. (2013). Affirmative old age-The ageing body and feminist theories on difference. International Journal of Ageing and Later Life, 8(1), 11-40. 
Sandvin, J.T. (2008). Ålder och funktionshinder [Age and disability]. In L. Grönvik \& M. Söder (Eds.), Bara funktionshindrad? Funktionshinder och intersektionalitet [Just disabled? Disability and intersectionality] (pp. 64-88). Malmö: Gleerups.

Scheidt, R.J., Humpherys, D.R. \& Yorgason, J.B. (1999). Successful aging: What's not to like? The Journal of Applied Gerontology, 18(3), 277-282.

Seale, C. (1999). Quality in qualitative research. Qualitative Inquiry, 5(4), 465-478.

Sevenhuijsen, S. (1998). Citizenship and the ethics of care. Feminist considerations on justice, morality and politics. London: Routledge.

SFS 1993:387 (Swedish Code of Statutes). Lag om stöd och service till vissa funktionshindrade [Act concerning support and service for persons with certain functional impairments].

SFS 2003:460 (Swedish Code of Statutes). Lag om etikprövning av forskning som avser människor [Act on ethical review for research involving humans].

Shakespeare, T. (2000a). Help. Birmingham: Venture Press.

Shakespeare, T. (2000b). The social relations of care. In G. Lewis, S. Gewirtz \& J. Clarke (Eds.), Rethinking social policy. London: Sage.

Shakespeare, T. (2004). Social models of disability and other life strategies. Scandinavian Journal of Disability Research, 6(1), 8-21.

Shakespeare, T. (2006). Disability rights and wrongs. New York: Routledge.

Shakespeare, T., Gillespie-Sells, K. \& Davies, D. (1996). The sexual politics of disability: Untold desires. London: Cassell.

Shakespeare, T. \& Watson, N. (2001). The social model of disability: An outdated ideology? Research in Social Science and Disability, 2(1), 9-28.

Spindel, A., Campbell, M. \& Mendez, J. (2012). Bringing stakeholders together across ageing and disability: GOWD conference series. International Journal of Integrated Care, 12(16), 1-4.

Stebbins, R.A. (2001). Exploratory research in the social sciences. Thousand Oaks: Sage.

Strawbridge, W.J., Wallhagen, M.I. \& Cohen, R.D. (2002). Successful aging and well-being: Self-rated compared with Rowe and Kahn. The Gerontologist, 42(6), 727-733.

Swedish Research Council (Vetenskapsrådet). (2002) Forskningsetiska principer inom humanistisk-samhällsvetenskaplig forskning [Research ethics principles in humanistic-social scientific research]. Stockholm: Vetenskapsrådet.

Swedish Research Council (Vetenskapsrådet). (2011). God forskningsed [Good research practice] (Vetenskapsrådets Rapportserie 1:2001). Stockholm: Vetenskapsrådet.

Swedish Research Institute for Disability Policy. (2005). Levnadsnivåundersökning 2005. En rapport om levnadsnivån för rörelsehindrade, hörselskadade, döva och synskadade personer [Living conditions 2005. A report on living conditions for people with impaired mobility, deaf and visually impaired]. Stockholm: HANDU. 
Szebehely, M. (2005). Anhörigas betalda och obetalda äldreomsorgsinsatser [Relatives' paid and unpaid care for the elderly]. In Forskarrapporter till jämställdhetspolitiska utredningen [Research reports on gender equality policy] (Swedish Government Official Report SOU 2005:66). Stockholm: Fritzes.

Szebehely, M. \& Trydegård, G-B. (2007). Omsorgstjänster för äldre och funktionshindrade: Skilda villkor, skilda trender? [Care services for older people and people with disabilities: Different conditions, diverging trends?]. Socialvetenskaplig Tidskrift, 14(2-3), 197-219.

Söder, M. (2003). Normalisering, handikappolitik och forskning [Normalization, disability policy and research]. In B. Nirje (Ed.), Normaliseringsprincipen [The principle of normalization] (pp. 189-210). Lund: Studentlitteratur.

Taghizadeh Larsson, A. (2009). Att åldras med funktionshinder [Ageing with disability]. Doctoral dissertation, Linköping University, Department of Social and Welfare Studies.

Taghizadeh Larsson, A. (2012). Informell omsorg som problem: Anhörigskap, funktionshinder och vuxenhet [Informal care as a problem: Familial relationships, disability and adulthood]. In E. Jeppsson Grassman \& A. Whitaker (Eds.), Aldrande och omsorgens gestaltningar [Ageing and forms of care] (pp. 57-76). Lund: Studentlitteratur.

Taylor, S.J. \& Bogdan, R. (1998). Introduction to qualitative research methods. New York: John Wiley and Sons.

Taylor, B. \& de Vocht, H. (2011). Interviewing separately or as couples? Considerations of authenticity of method. Qualitative Health Research, 21(11), 1576-1587.

Thomas, C. (1993). De-constructing concepts of care. Sociology, 27(4), 649-669.

Thomas, C. (1997). The baby and the bath water: Disabled women and motherhood in social context. Sociology of Health and Illness, 19(5), 622-643.

Thomas, C. (2004). How is disability understood? An examination of sociological approaches. Disability and Society, 19(6), 569-583.

Thomas, G. \& James, D. (2006). Reinventing grounded theory: Some questions about theory, ground and discovery. British Educational Research Journal, 32(6), 767-795.

Thorsen, K. (2003). ^̊ falle mellom alle stoler?-Om aldring blant funksjonshemmede mennesker [To be caught between stools?-On ageing among people with disabilities]. Nordisk sosialt arbeid, 1, 46-55.

Thorsen, K. \& Jeppsson Grassman, E. (2012). Livsløp med funksjonshemming [Lifecourse with disabilities]. Oslo: Cappelen Damm.

Tronto, J.C. (1993). Moral boundaries. A political argument for an ethic of care. New York: Routledge.

Twigg, J. (2000). Carework as a form of bodywork. Ageing and Society, 20(4), 389411. 
Tøssebro, J. (2010). Hva er funksjonshemming [What is disability]. Oslo: Universitetsforlaget.

Union of the Physically Impaired Against Segregation. (1975). Fundamental Principles of Disability. Accessed 04 November 2013 from http://www.leeds.ac.uk/disabilitystudies/archiveuk/UPIAS/fundamental\%20principles.pdf

van Nes, F., Runge, U. \& Jonsson, H. (2009). One body, three hands and two minds: A case study of the intertwined occupations of an older couple after a stroke. Journal of Occupational Science, 16(3), 194-202.

Verbrugge, L. \& Yang, L. (2002). Aging with disability and disability with aging. Journal of Disability Policy Studies, 12(4), 253-267.

Walker, A. \& Walker, C. (1998). Normalisation and "normal" ageing: The social construction of dependency among older people with learning difficulties. Disability and Society, 13(1), 125-142.

Walker, R.B. \& Luszcz, M.A. (2009). The health and relationship dynamics of latelife couples: A systematic review of the literature. Ageing and Society, 29(3), 455-480.

Wang, Q. (2005). Disability and American families: 2000 (Census 2000 Special Reports). Washington, D.C.: US Census Bureau.

Washko, M.M., Campbell, M. \& Tilly, J. (2012). Accelerating the transition of research into practice in long term services and supports: A critical need for federal infrastructure at the nexus of aging and disability. Journal of Gerontological Social Work, 55(2), 112-125.

Watson, N., McKie, L., Hughes, B., Hopkins, D. \& Gregory, S. (2004). (Inter)Dependence, needs and care: The potential for disability and feminist theorists to develop an emancipatory model. Sociology, 38(2), 331-350.

Wells, K. (1995). The strategy of grounded theory: Possibilities and problems. Social Work Research, 19(1), 33-37.

Wenger, G.C. (1990). Elderly carers: The need for appropriate intervention. Ageing and Society, 10(2), 197-219.

Whitaker, A. (2013). In the shade of disability reforms and policy: Parenthood, ageing and lifelong care. In E. Jeppsson Grassman \& A. Whitaker (Eds.), Ageing with disability: A lifecourse perspective (pp. 91-108). Bristol: Policy Press.

World Health Organization. (2001). International classification of functioning, disability and health. Geneva: WHO.

Wærness, K. (1996). The rationality of caring. In S. Gordon, P. Benner \& N. Noddings (Eds.), Caregiving: Readings in knowledge, practice, ethics, and politics (pp. 231-255). Philadelphia, PA: University of Pennsylvania Press.

Yorkston, K.M, McMullan, K.A., Molton, I., \& Jensen, M.P. (2010). Pathways of change experienced by people aging with disability: A focus group study. Disability and Rehabilitation, 32(20), 1697-1704. 



\section{Appendix}

\section{Interview guide in Swedish (2010)}

Funktionsnedsättningar - Hur gamla är ni? Vad har ni för typ av funktionsnedsättningar? Sedan hur lång tid tillbaka har ni era funktionsnedsättningar? Vad har dina funktionsnedsättningar inneburit för dig? Hur har de förändrats eller utvecklats över tiden? Tror du att ditt funktionshinder har betydelse för hur du blir bemött av andra?

Att vara ett par med funktionshinder - När och hur träffades ni? Vilka funktionshinder hade ni, när ni började leva i par? Hade det någon betydelse att den andra också hade funktionshinder - socialt, praktiskt eller på annat sätt? Hur såg andra i er omgivning på att ni båda hade funktionshinder? Har ni haft andra parrelationer tidigare i livet? Hade den partnern också något funktionshinder?

Hjälpbehov - Vad har era funktionshinder inneburit för er vardag? Vilka uppgifter i hemmet/utanför hemmet behöver ni hjälp med? Vilka uppgifter får ni regelbunden hjälp med, om någon? Hur ser en vanlig dag ut? Har åldern inneburit ökande hjälpbehov?

Hjälp från andra - Får ni hjälp av någon? Vem? Med vilka uppgifter hjälper de er? Hur viktig är andras hjälp för att ni ska kunna leva självständigt tillsammans?

Hjälp från partnern - Hjälper ni också varandra i vardagen? Vilka sorters hjälp kan det handla om-medicinering, att klara en aktivitet eller något annat? Vem är det som ger den hjälpen till vem? Vilka hjälpbehov kan uppstå när ni är ensamma? Hur löser ni dem? Är det "helt naturligt" och går det automatiskt för er att hjälpa varandra? Varför är det så, eller inte så? Vilka uppgifter vill du helst få hjälp med av andra, vilka av din partner? Varför?

Att båda åldras med funktionshinder - Är det en tillgång eller en nackdel att ni har samma/olika typer av funktionshinder? Vad finns det för nackdelar, om några, med att båda har funktionshinder? Har livet med funktionshinder blivit lättare eller svårare över tid? Vad tänker ni på, när ni tänker på era funktionshinder i framtiden? 


\section{Interview guide in Swedish (20 I 2)}

Förändringar sedan sist - Vad har hänt sedan vi träffades sist, för två år sedanmed kroppen, sociala förändringar, boende, hjälpbehov och generella förhållanden? Hur ser era funktionsnedsättningar ut idag-sämre, bättre, oförändrade? Hur fungerar tillvaron jämfört med sist? Har er vardag blivit annorlunda i och med att ni båda har blivit äldre? Påverkar åldrandet er vardag? Märker ni att tiden har gått, och i så fall på vilket sätt? Hur känns de här åren?

Ålder, funktionshinder och aktivitet - (gäller för dem som har pensionerat sig sedan sist): Hur är livet nu för er som pensionärer? Innebär det en ökning i aktivitet eller har ni minskat ned på aktiviteter? (Till alla): Har era funktionshinder/åldrande inneburit minskad aktivitet om du jämför med hur det var för två år sedan?

Att ge och ta emot hjälp - Behöver ni mera hjälp nu, jämfört med vid förra intervjun? Behöver ni ge mer hjälp till varandra idag än då? Med vad? Hur påverkar funktionshindret möjligheten att kunna hjälpa till? Vad har ni för tankar om den närmaste framtiden-om funktionshinder, om åldrandet, om ert liv tillsammans, och om era planer för dem kommande åren? 


\section{Papers}

The articles associated with this thesis have been removed for copyright reasons. For more details about these see:

http://urn.kb.se/resolve?urn=urn:nbn:se:liu:diva-104808 